This is an electronic reprint of the original article. This reprint may differ from the original in pagination and typographic detail.

Author(s): Ghosh, Biswa Nath; Topic, Filip; Sahoo, Prasit Kumar; Mal, Prasenjit; Linnera, Jarno; Kalenius, Elina; Tuononen, Heikki; Rissanen, Kari

Title: $\quad$ Synthesis, structure and photophysical properties of a highly luminescent terpyridinediphenylacetylene hybrid fluorophore and its metal complexes

Year: $\quad 2015$

Version:

Please cite the original version:

Ghosh, B. N., Topic, F., Sahoo, P. K., Mal, P., Linnera, J., Kalenius, E., Tuononen, H., \& Rissanen, K. (2015). Synthesis, structure and photophysical properties of a highly luminescent terpyridine-diphenylacetylene hybrid fluorophore and its metal complexes. Dalton Transactions, 44(1), 254-267. https://doi.org/10.1039/c4dt02728k

All material supplied via JYX is protected by copyright and other intellectual property rights, and duplication or sale of all or part of any of the repository collections is not permitted, except that material may be duplicated by you for your research use or educational purposes in electronic or print form. You must obtain permission for any other use. Electronic or print copies may not be offered, whether for sale or otherwise to anyone who is not an authorised user. 


\title{
Synthesis, Structure and Photophysical Properties of a Highly Luminescent Terpyridine-Diphenylacetylene Hybrid Fluorophore and its Metal Complexes
}

\author{
Biswa Nath Ghosh, ${ }^{a, b}$ Filip Topić, ${ }^{a}$ Prasit Kumar Sahoo, ${ }^{c}$ Prasenjit Mal, ${ }^{*, c}$ Jarno \\ Linnera, ${ }^{a}$ Elina Kalenius, ${ }^{a}$ Heikki M. Tuononen*, ${ }^{*}$ and Kari Rissanen ${ }^{* a}$
}

\begin{abstract}
A new fluorescent terpyridyl-diphenylacetylene hybrid fluorophore 4'-[4- $\{4$ -

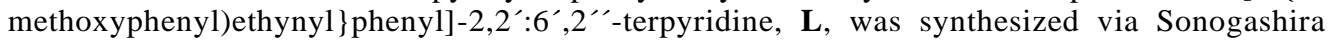
cross-coupling of 4'-(4-bromophenyl)-2,2':6',2"'-terpyridine and 4-ethynylanisole in the presence of $\mathrm{Pd}\left(\mathrm{PPh}_{3}\right)_{4} / \mathrm{CuI}$ as a catalyst. The solid state structure of $\mathbf{L}$ shows a trans arrangement of pyridine nitrogen atoms along the interannular bond in the terpyridine domain. Five transition metal complexes of $\mathbf{L},\left\{\left[\mathrm{FeL}_{2}\right]\left(\mathrm{CF}_{3} \mathrm{SO}_{3}\right)_{2}(\mathbf{1}),\left[\mathrm{ZnL}_{2}\right]\left(\mathrm{ClO}_{4}\right)_{2}(\mathbf{2}),\left[\mathrm{Cd}_{2}\right]\left(\mathrm{ClO}_{4}\right)_{2}\right.$ (3), $\left[\mathrm{RuL}_{2}\right]\left(\mathrm{PF}_{6}\right)_{2}(\mathbf{4})$, and $\left.\mathrm{PtMe}_{3} \mathrm{IL}(\mathbf{5})\right\}$, have also been synthesized and characterized by spectroscopic methods and single crystal X-ray analysis. The X-ray crystal structures of complexes 1-3 show a distorted octahedral $\mathrm{MN}_{6}$ arrangement with tridentate coordination of the two terpyridine ligands, whereas in complex $\mathbf{5}$ the ligand $\mathbf{L}$ binds in bidentate fashion. The ligand $\mathbf{L}$ displays bright blue emission in the solid state and in both non-polar and polar organic media. The fluorescence quantum yield of $\mathbf{L}$ is exceptionally high for a monoterpyridine ligand of its kind, which can be rationalized with density functional theory calculations. The electronic structure of $\mathbf{L}$ shows that the fluorescence involves intramolecular charge transfer from the diphenylacetylene moiety to the terpyridine group, and it is not affected by the usual non-radiative relaxation processes such as pyridine rotation. The Fe(II), $\mathrm{Ru}(\mathrm{II})$ and $\mathrm{Pt}(\mathrm{IV})$ complexes of $\mathbf{L}$ were found to be non-emissive, whereas both $\mathrm{Zn}$ (II) and Cd(II) complexes displayed significant green emission attributed to intra-ligand charge transfer states. These results were supported by the observed red-shift of the emission maxima of complexes $\mathbf{2}$ and $\mathbf{3}$ upon increasing the solvent polarity.
\end{abstract}

\section{Introduction}

The well-known 2,2':6',2"'-terpyridine and its derivatives represent an important class of ligands in the fields of supramolecular and coordination chemistry as well as material science. ${ }^{1}$ Their strong chelating properties, stemming from the arrangement of the three pyridinic nitrogen atoms, along with the extremely strong binding affinity towards most transition metal ions make terpyridines highly useful building blocks for the creation of wide range of systems with interesting photophysical, electrochemical, and catalytic properties. ${ }^{2}$ Consequently, 2,2':6',2"'-terpyridine and its transition metal complexes have been explored extensively for use in dyesensitized solar cells, ${ }^{3}$ two-photon luminescent systems, ${ }^{4}$ mixed-valence chemistry, ${ }^{2 b, 5}$ as well as electrochromic ${ }^{6}$ and organic light-emitting devices. ${ }^{7}$ In addition, terpyridines have often been used in the construction of self-assembled hydrogels $^{8}$ with myriad applications in organic-inorganic hybrid materials, medicines, and optoelectronics. ${ }^{9}$

Fluorescence response from metallo-terpyridine complexes, especially those with $\mathrm{Zn}^{2+}$, has recently prompted the development of new sensors for bio-assays and in vivo imaging purposes. ${ }^{10}$ It is unfortunate that many terpyridine derivatives have low quantum yields due to efficient non-radiative relaxation processes, and any significant emission can only be achieved after specific modifications to the terpyridine backbone. ${ }^{11}$ For this reason, considerable research effort has been invested in examining the structure-function relationships in terpyridines to intelligently tune their luminescence properties. It has been established that the emission of $2,2^{\prime}: 6^{\prime}, 2^{\prime \prime}$-terpyridines can be greatly influenced by introducing a conjugated moiety at the $4^{\prime}$ position. ${ }^{12}$ In this context, it is somewhat surprising that there exist only very few structural reports of $4^{\prime}$ substituted terpyridine derivatives with 1,2diphenylacetylene (tolan), one of the archetypical organic fluorophores. ${ }^{13}$ To the best of our knowledge, the crystal structure of a $\mathrm{Fe}_{2}(\mathrm{CO})_{6}(\mu$-azadithiolate) cluster bearing a pendant terpyridine domain with an alkynylphenylene spacer represents the only structurally characterized example in the literature, ${ }^{14}$ but the authors did not study its fluorescence properties.

Herein, we report the synthesis and crystal structure of a new monoterpyridine ligand L, 4'-[4-\{4-

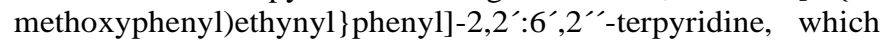
merges the diphenylacetylene moiety with the terpyridine framework and shows strong blue fluorescence both in solution and in the solid state. The syntheses and crystal structures of several transition metal complexes of $\mathbf{L}$ are also described, 
$\left\{\left[\mathrm{FeL}_{2}\right]\left(\mathrm{CF}_{3} \mathrm{SO}_{3}\right)_{2}(\mathbf{1}),\left[\mathrm{ZnL}_{2}\right]\left(\mathrm{ClO}_{4}\right)_{2}(\mathbf{2}),\left[\mathrm{CdL}_{2}\right]\left(\mathrm{ClO}_{4}\right)_{2}(\mathbf{3})\right.$, $\left[\mathrm{RuL}_{2}\right]\left(\mathrm{PF}_{6}\right)_{2}$ (4), and $\mathrm{PtMe}_{3} I \mathbf{L}$ (5) $\}$, along with their photophysical properties in the solid state and in different solvent systems. The ligand $\mathbf{L}$ binds to divalent metal ions $\left(\mathrm{Fe}^{2+}, \mathrm{Zn}^{2+}, \mathrm{Cd}^{2+}\right.$, and $\left.\mathrm{Ru}^{2+}\right)$ in tridentate fashion, whereas a bidentate complex is obtained with trimethylplatinum(IV) iodide. Even though the $\mathrm{Cd}^{2+}$ and $\mathrm{Zn}^{2+}$ complexes of $\mathbf{L}$ exhibit strong fluorescence in both investigated phases, fluorescence quenching was observed upon complexation of the ligand with other d-block metal ions examined. The photophysical properties of $\mathbf{L}$ were also studied with density functional theory (DFT) calculations in order to explain the origin of its fluorescence.

\section{Experimental section}

\section{Materials and methods}

All chemicals and solvents were of analytical reagent grade, purchased commercially, and used as received. The starting compound $\quad 4^{\prime}$-(4-bromophenyl)-2,2':6 $6^{\prime}, 2^{\prime \prime}$-terpyridine was synthesized following a literature procedure ${ }^{15}$ Caution!!! Although no problems were encountered in this work, transition metal perchlorates are potentially explosive. Only a small amount of the materials should be prepared at time and handled with great care.

${ }^{1} \mathrm{H}$ and ${ }^{13} \mathrm{C}$ NMR spectra were recorded on Bruker Avance DRX 400 and DRX 500 spectrometers (see ESI $\dagger$ ). The mass spectra were measured on a QSTAR Elite ESI-Q-TOF mass spectrometer equipped with an API 200 TurboIonSpray ESI source from $\mathrm{AB}$ Sciex (former MDS Sciex). Elemental analyses of the metal complexes were performed with an Elementar Analysesysteme GmbH VariolEL.

\section{Spectroscopic studies}

UV-Vis absorption spectra were recorded on a Varian Cary 100 Conc UV-Vis spectrophotometer, whereas solution state emission spectra were obtained with a Varian Cary Eclipse Fluorescence spectrophotometer. Fluorescence quantum yields were measured using quinine sulfate as the standard $\left(\Phi_{\mathrm{F}}=0.546\right.$ in $\left.0.1 \mathrm{~N} \mathrm{H}_{2} \mathrm{SO}_{4}\right)$. Fluorescence decays in different solvents in the sub-nanosecond and nanosecond timescales were measured using a time-correlated single photon counting (TCSPC) system consisting of a HydraHarp 400 controller and a PDL 800-B driver from PicoQuant GmBH. Measurements were carried out at room temperature and under ambient conditions. Solid state emission spectra were measured using a Perkin-Elmer LS 55 spectrofluorimeter. Fluorescence decays in the solid state were measured using a time-correlated singlephoton counting (TCSPC) spectrometer OB920 from Edinburgh.

Synthesis of $4^{\prime}-[4-\{4-m e t h o x y p h e n y l) e t h y n y l\}$ phenyl]-2,2':6 $6^{\prime}, 2^{\prime \prime}-$ terpyridine (L). 4'-(4-bromophenyl)-2,2':6 , $2^{\prime \prime}$-terpyridine (2 g, $5.15 \mathrm{mmol})$ was dissolved in freshly distilled toluene $(80 \mathrm{~mL})$ and argon was bubbled through the solution for $15 \mathrm{~min} . \mathrm{Pd}\left(\mathrm{PPh}_{3}\right)_{4}(0.60$ $\mathrm{g}, 0.519 \mathrm{mmol})$ and $\mathrm{CuI}(0.147 \mathrm{~g}, 0.772 \mathrm{mmol})$ were added and the solution was degassed. Finally, 4-ethynylanisole $(1.53 \mathrm{~g}, 11.6 \mathrm{mmol})$ and freshly distilled triethylamine $(20 \mathrm{~mL})$ were added and the resulting mixture was refluxed for $24 \mathrm{~h}$. After cooling down, the solution was diluted with dichloromethane and a small amount of charcoal was added and filtered over celite. The filtrate was washed with saturated $\mathrm{NH}_{4} \mathrm{Cl}$ and brine, dried with $\mathrm{MgSO}_{4}$, and evaporated to get the crude product. The crude product was purified by column chromatography ( $10 \%$ ethyl acetate in $n$-hexane). Slow diffusion of chloroform into methanol solution of $\mathbf{L}$ at room temperature afforded yellowish-orange crystals suitable for X-ray diffraction.
Yield 78\%. ${ }^{1} \mathrm{H}$ NMR $\left(400 \mathrm{MHz}, \mathrm{CDCl}_{3}, 27{ }^{\circ} \mathrm{C}\right) \delta / \mathrm{ppm}: 8.76(\mathrm{~s}, 2 \mathrm{H})$, 8.73-8.75 (m, 2H), $8.68(\mathrm{~d}, 2 \mathrm{H}, J 8.0 \mathrm{~Hz}), 7.91(\mathrm{dt}, 2 \mathrm{H}, J 1.8,8.1$ $\mathrm{Hz}), 7.88(\mathrm{dd}, 2 \mathrm{H}, J 1.8,7.8 \mathrm{~Hz}), 7.66(\mathrm{dt}, 2 \mathrm{H}, J 1.8,8.3 \mathrm{~Hz}), 7.51$ $(\mathrm{dt}, 2 \mathrm{H}, J 1.8,8.8 \mathrm{~Hz}), 7.34-7.37(\mathrm{~m}, 2 \mathrm{H}), 6.91(\mathrm{dt}, 2 \mathrm{H}, J 2.0,8.8$ $\mathrm{Hz}), 3.85$ (s, 3H). ${ }^{13} \mathrm{C}$ NMR $\left(100 \mathrm{MHz}, \mathrm{CDCl}_{3}, 27{ }^{\circ} \mathrm{C}\right) \delta / \mathrm{ppm}$ : $159.79,156.20,156.05,149.48,149.17,137.80,136.90,133.16$, $131.99,127.24,124.43,123.89,121.39,118.65,115.24,114.07$, 90.95, 87.89, 55.34. MS (ESI-TOF) $[\mathbf{L}+\mathrm{Na}]^{+} \mathrm{m} / z, 462.1573$ (Calcd. 462.1577).

Synthesis of $\left[\mathrm{FeL}_{2}\right]\left(\mathrm{CF}_{3} \mathrm{SO}_{2}\right)_{2}$ (1). To a degassed acetonitrile solution $(10 \mathrm{~mL})$ of $\mathrm{Fe}\left(\mathrm{CF}_{3} \mathrm{SO}_{2}\right)_{2}(20 \mathrm{mg}, 0.057 \mathrm{mmol}), 50.0 \mathrm{mg}$ $(0.114 \mathrm{mmol})$ of ligand $\mathbf{L}$ was added and the reaction mixture was stirred at room temperature for $1 \mathrm{~h}$. The mixture was then concentrated after which an excess of diethyl ether $(30 \mathrm{~mL})$ was added slowly. The resultant purple solid, 1, was filtered, washed with diethyl ether, and dried under vacuum. Yield $86 \%(60 \mathrm{mg})$. The salt 1 was crystallized as purple crystals upon slow diffusion of diisopropyl ether into its acetonitrile solution at room temperature. ${ }^{1} \mathrm{H}$ NMR (400 MHz, CD $3 \mathrm{CN}, 27{ }^{\circ} \mathrm{C}$ ) $\delta / \mathrm{ppm}: 9.21(\mathrm{~s}, 4 \mathrm{H}), 8.63(\mathrm{~d}$, $4 \mathrm{H}, J 7.9 \mathrm{~Hz}), 8.36(\mathrm{dt}, 4 \mathrm{H}, J 1.8,8.4 \mathrm{~Hz}), 7.89-7.95(\mathrm{~m}, 8 \mathrm{H}), 7.59$ $(\mathrm{dt}, 4 \mathrm{H}, J 2.0,8.8 \mathrm{~Hz}), 7.20(\mathrm{~d}, 4 \mathrm{H}, J 5.6 \mathrm{~Hz}), 7.09(\mathrm{td}, 4 \mathrm{H}, J 1.2,6.8$ $\mathrm{Hz}$ ), $7.03(\mathrm{dt}, 4 \mathrm{H}, J 2.0,8.8 \mathrm{~Hz}), 3.87(\mathrm{~s}, 6 \mathrm{H})$. MS (ESI-TOF) $\left[\mathrm{FeL}_{2}\right]^{2+} \mathrm{m} / \mathrm{z} 467.1353$ (Calcd. 467.1354), $\left[\mathrm{Fe} \mathbf{L}_{2}+\mathrm{CF}_{3} \mathrm{SO}_{3}\right]^{+} \mathrm{m} / \mathrm{z}$ 1083.2239 (Calcd. 1083.2233). Anal. Calcd. for $\mathrm{C}_{62} \mathrm{H}_{42} \mathrm{~F}_{6} \mathrm{FeN}_{6} \mathrm{O}_{8} \mathrm{~S}_{2}$ (1233.00): C, 60.39; H, 3.43; N, 6.82. Found: C, 60.12; H, 3.62; N, $6.72 \%$.

Synthesis of $\left[\mathrm{ZnL}_{2}\right]\left(\mathrm{ClO}_{4}\right)_{2}(2)$. To an acetonitrile solution $(10 \mathrm{~mL})$ of $\mathrm{Zn}\left(\mathrm{ClO}_{4}\right)_{2} \cdot 6 \mathrm{H}_{2} \mathrm{O}(20 \mathrm{mg}, 0.054 \mathrm{mmol}), 47.2 \mathrm{mg}(0.107 \mathrm{mmol})$ of ligand $\mathbf{L}$ in $10 \mathrm{~mL}$ dichloromethane was added and the reaction mixture was stirred at room temperature for $2 \mathrm{~h}$. The resultant mixture was then concentrated and evaporated to dryness to afford a greenish-yellow product. The product was re-dissolved in a minimal volume of acetonitrile and excess of diethyl ether $(25 \mathrm{~mL})$ was added to precipitate 2 . The precipitate was filtered, washed again several times with diethyl ether, and dried in vacuum. Yield $81 \%$ (50 $\mathrm{mg}$ ). Slow diffusion of diisopropyl ether into a 2:1 mixture of acetonitrile and dichloromethane at room temperature afforded yellow crystals. ${ }^{1} \mathrm{H}$ NMR $\left(400 \mathrm{MHz}, \mathrm{CD}_{3} \mathrm{CN}, 2{ }^{\circ} \mathrm{C}\right) \delta / \mathrm{ppm}: 8.99$ (s, $4 \mathrm{H}), 8.72(\mathrm{~d}, 4 \mathrm{H}, J 8.1 \mathrm{~Hz}), 8.15-8.24(\mathrm{~m}, 4 \mathrm{H}), 7.88(\mathrm{~d}, 4 \mathrm{H}, J 8.4$ $\mathrm{Hz}), 7.84(\mathrm{~d}, 4 \mathrm{H}, J 4.5 \mathrm{~Hz}), 7.57(\mathrm{dt}, 4 \mathrm{H}, J$ 2.1, $8.8 \mathrm{~Hz}), 7.41$ (dd, $4 \mathrm{H}, J 1.5,5.9 \mathrm{~Hz}), 7.02(\mathrm{~d}, 4 \mathrm{H}, J 8.9 \mathrm{~Hz}), 3.86(\mathrm{~s}, 6 \mathrm{H})$. MS (ESITOF) $\left[\mathrm{ZnL}_{2}\right]^{2+} \mathrm{m} / \mathrm{z} 471.1346$ (Calcd. 471.1325), $\left[\mathrm{ZnL}_{2}+\mathrm{ClO}_{4}\right]^{+} \mathrm{m} / \mathrm{z}$ 1043.212 (Calcd. 1043.2127). Anal. Calcd. for $\mathrm{C}_{60} \mathrm{H}_{42} \mathrm{Cl}_{2} \mathrm{~N}_{6} \mathrm{O}_{10} \mathrm{Zn}$ (1143.30): C, 63.03; H, 3.70; N, 7.35. Found: C, 63.39; H, 3.93; N, $7.02 \%$.

Synthesis of $\left[\mathrm{CdL}_{2}\right]\left(\mathrm{ClO}_{4}\right)_{2}(3)$. To an acetonitrile solution $(10 \mathrm{~mL})$ of $\mathrm{Cd}\left(\mathrm{ClO}_{4}\right)_{2} \cdot 6 \mathrm{H}_{2} \mathrm{O}(24.2 \mathrm{mg}, 0.058 \mathrm{mmol}), 51.8 \mathrm{mg}(0.118 \mathrm{mmol})$ of ligand $\mathbf{L}$ in $10 \mathrm{~mL}$ dichloromethane was added and the reaction mixture was stirred at room temperature for $3 \mathrm{~h}$. The resultant mixture was then concentrated and evaporated to dryness. The product was re-dissolved in a minimal volume of acetonitrile and excess of diethyl ether $(25 \mathrm{~mL})$ was added to precipitate a yellow product, 3 . The precipitate was filtered, washed again several times with diethyl ether, and dried in vacuum. Yield 79\% (54 mg). The product was crystallized upon slow diffusion of diisopropyl ether into its acetonitrile solution at room temperature. ${ }^{1} \mathrm{H}$ NMR (400 $\left.\mathrm{MHz}, \mathrm{CD}_{3} \mathrm{CN}, 2{ }^{\circ} \mathrm{C}\right) \delta / \mathrm{ppm}: 8.95(\mathrm{~s}, 4 \mathrm{H}), 8.76(\mathrm{~d}, 4 \mathrm{H}, J 8.1 \mathrm{~Hz})$, 8.18-8.24 (m, 8H), 8.09 (br s, 4H), 7.85 (d, 4H, J 8.4 Hz), 7.57 (d, $4 \mathrm{H}, J 8.8 \mathrm{~Hz}), 7.50(\mathrm{dd}, 4 \mathrm{H}, J 1.4,6.0 \mathrm{~Hz}), 7.01(\mathrm{~d}, 4 \mathrm{H}, J 8.8 \mathrm{~Hz})$, $3.86(\mathrm{~s}, 6 \mathrm{H})$. MS (ESI-TOF) $\left[\mathrm{CdL}_{2}\right]^{2+} \mathrm{m} / z \quad 496.1186$ (Calcd. 496.1196), [CdL $\left.\mathbf{L}_{2}+\mathrm{ClO}_{4}\right]^{+} \mathrm{m} / \mathrm{z} 1091.1817$ (Calcd. 1091.1883). Anal. 
Calcd. for $\mathrm{C}_{60} \mathrm{H}_{42} \mathrm{CdCl}_{2} \mathrm{~N}_{6} \mathrm{O}_{10}$ (1190.33): C, 60.54; H, 3.56; N, 7.06. Found: C, 60.32; H, 3.41; N, 6.85\%.

Synthesis of [RuL $\mathbf{R}_{2}$ ( $\left.\mathbf{P F}_{\mathbf{6}}\right)_{2} \mathbf{( 4 )} . \mathrm{RuCl}_{3} \cdot 3 \mathrm{H}_{2} \mathrm{O}$ (20 mg, $\left.0.076 \mathrm{mmol}\right)$ and ligand $\mathbf{L}(33.6 \mathrm{mg}, 0.076 \mathrm{mmol})$ were added to $20 \mathrm{~mL}$ of methanol and the solution was heated to reflux for $3 \mathrm{~h}$. The brownish precipitate which formed was filtered off and air dried to give 38.5 $\mathrm{mg}$ of $\left[\mathrm{RuCl}_{3} \mathbf{L}\right]$. The product was suspended in methanol $(20 \mathrm{~mL})$ with $26.2 \mathrm{mg}(0.06 \mathrm{mmol})$ of $\mathbf{L}$, after which 4 drops of 4ethylmorpholine was added and the mixture was heated to reflux for another $4 \mathrm{~h}$. The resulting solution was allowed to cool and excess of aqueous $\mathrm{NH}_{4} \mathrm{PF}_{6}$ was added to the solution. The formed dark red precipitate was filtered and washed several times with water. The precipitate was then re-dissolved in a minimal volume of acetonitrile and excess of diethyl ether was added to give a bright red product, $\mathbf{4}$, which was filtered and washed several times with diethyl ether. Yield 59\% (57 mg). ${ }^{1} \mathrm{H} \mathrm{NMR}\left(500 \mathrm{MHz}, \mathrm{CD}_{3} \mathrm{CN}, 30{ }^{\circ} \mathrm{C}\right) \delta / \mathrm{ppm}$ : $9.03(\mathrm{~s}, 4 \mathrm{H}), 8.66(\mathrm{~d}, 4 \mathrm{H}, J 8.4 \mathrm{~Hz}), 8.25(\mathrm{dt}, 4 \mathrm{H}, J 1.9,8.5 \mathrm{~Hz}), 7.96$ (td, $4 \mathrm{H}, J 1.6,7.9 \mathrm{~Hz}), 7.89(\mathrm{dt}, 4 \mathrm{H}, J 2.0,8.5 \mathrm{~Hz}), 7.58(\mathrm{dt}, 4 \mathrm{H}, J$ $2.1,8.9 \mathrm{~Hz}$ ), 7.44 (br d, $4 \mathrm{H}, J 5.5 \mathrm{~Hz}$ ), 7.19 (ddd, $4 \mathrm{H}, J$ 0.5, 1.3, 6.4 $\mathrm{Hz}$ ), $7.02(\mathrm{dt}, 4 \mathrm{H}, J$ 2.0, $8.7 \mathrm{~Hz}), 3.86(\mathrm{~s}, 6 \mathrm{H})$. MS (ESI-TOF) $\left[\mathrm{RuL}_{2}\right]^{2+} \quad m / z \quad 490.1208$ (Calcd. 490.1201), $\left[\mathrm{RuL}_{2}+\mathrm{PF}_{6}\right]^{+} \mathrm{m} / \mathrm{z}$ 1125.2021 (Calcd. 1125.2049). Anal. Calcd. for $\mathrm{C}_{60} \mathrm{H}_{42} \mathrm{~F}_{12} \mathrm{~N}_{6} \mathrm{O}_{2} \mathrm{P}_{2} \mathrm{Ru}$ (1270.01): C, 56.74; H, 3.33; N, 6.62. Found: C, 56.94; H, 3.49; N, $6.81 \%$.

Synthesis of [PtMe $\mathrm{IL}$ ] (5). A solution of PtMe $\mathrm{I}$ (30 mg, 0.082 $\mathrm{mmol})$ in chloroform $(10 \mathrm{~mL})$ was added to a chloroform solution $(10 \mathrm{~mL})$ of $\mathbf{L}(35.9 \mathrm{mg}, 0.082 \mathrm{mmol})$, and the reaction mixture was stirred at $50{ }^{\circ} \mathrm{C}$ for $6 \mathrm{~h}$. The resulting yellow solution was then concentrated and excess of $n$-hexane was added. The formed paleyellow solid 5 was isolated, washed several times with $n$-hexane and dried in vacuum. Yield $79 \%(52 \mathrm{mg})$. The product was crystallized as yellow crystals by slow diffusion of $n$-hexane into its dichloromethane solution at room temperature. ${ }^{1} \mathrm{H}$ NMR $(500 \mathrm{MHz}$, $\left.\mathrm{CD}_{2} \mathrm{Cl}_{2},-60{ }^{\circ} \mathrm{C}\right) \delta / \mathrm{ppm}: 9.01(\mathrm{~d}, 1 \mathrm{H}, J 5.2 \mathrm{~Hz}), 8.73(\mathrm{~d}, 1 \mathrm{H}, J 7.9$ $\mathrm{Hz}), 8.68$ (d, 1H, J 4.0 Hz), 8.36 (br s, 1H), 8.33 (d, 1H, J $8.2 \mathrm{~Hz}$ ), 8.11 (br s, 1H), 8.07 (t, 1H, J 7.9 Hz), 7.83-7.88 (m, 1H), 7.79 (d, $2 \mathrm{H}, J 7.8 \mathrm{~Hz}), 7.59-7.64(\mathrm{~m}, 3 \mathrm{H}), 7.43-7.49(\mathrm{~m}, 3 \mathrm{H}), 6.88(\mathrm{~d}, 2 \mathrm{H}, J$ $8.2 \mathrm{~Hz}), 3.78(\mathrm{~s}, 3 \mathrm{H}), 1.50\left(\mathrm{~s}, 3 \mathrm{H},{ }^{2} J_{\mathrm{Pt}-\mathrm{H}} 73.80 \mathrm{~Hz}\right), 0.26\left(\mathrm{~s}, 3 \mathrm{H},{ }^{2} J_{\mathrm{Pt}-\mathrm{H}}\right.$ $71.9 \mathrm{~Hz}), 0.15$ (s, 3H, $\left.{ }^{2} J_{\mathrm{Pt}-\mathrm{H}} 70.2 \mathrm{~Hz}\right)$. MS (ESI-TOF) $\left[\mathrm{PtMe}_{3} \mathbf{L}\right]^{+} \mathrm{m} / \mathrm{z}$ 679.1963 (Calcd. 679.2031). Anal. Calcd. for $\mathrm{C}_{33} \mathrm{H}_{30} \mathrm{IN}_{3} \mathrm{OPt}$ (806.60): C, 49.14; H, 3.75; N, 5.21. Found: C, 48.95; H, 3.49; N, $5.12 \%$.

\section{Crystal structure determinations}

X-ray diffraction data for single crystals of $\mathbf{L}$ and $\mathbf{1}$ were collected using a Bruker-Nonius KappaCCD diffractometer equipped with an

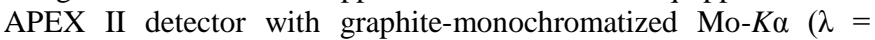
$0.71073 \AA$ ) radiation at $123 \mathrm{~K}$. Collect software was used for data collection $^{16}$ and DENZO-SMN for its processing. ${ }^{17}$ Absorption correction was applied with the multi-scan $S A D A B S$ program. ${ }^{18}$ Diffraction data for 2, 3, and $\mathbf{5}$ were collected at $123 \mathrm{~K}$ on an Agilent SuperNova Dual diffractometer equipped with an Atlas detector. CrysAlis ${ }^{P R O}$ program was used for data collection and processing. ${ }^{19}$ The intensities were corrected for absorption using the built-in absorption correction method. ${ }^{20}$ The structures were solved with the program Superflip ${ }^{21}$ and refined by full-matrix least squares on $F^{2}$ using the WinGX ${ }^{22}$ software equipped with SHELXL-2013.23 All non-hydrogen atoms were refined with anisotropic thermal parameters. All hydrogen atoms were calculated to their optimal positions and treated as riding atoms using isotropic displacement parameters 1.2 larger than the respective host atoms. The figures were drawn using the program Mercury v3.3.24
Further refinement details for 2. Perchlorate anions were modelled as disordered over two positions each, with their respective relative occupancies refined freely. Their geometries were restrained to be tetrahedral, with $\mathrm{Cl} \cdots \mathrm{O} 1,2-$ and $\mathrm{O} \cdots \mathrm{Cl} \cdots \mathrm{O}$ 1,3-distances tied to a free variable which was then also refined. One of the acetonitrile molecules was partially substituted by a dichloromethane molecule. Its geometry was restrained to be the same as that of a well-ordered acetonitrile molecule also present in the structure, while the $\mathrm{C}-\mathrm{Cl}$ bond lengths of the dichloromethane component were restrained to be equal. The relative occupancies of these two disorder components were allowed to refine freely. Restraints were also applied to the anisotropic displacement parameters of the disordered parts.

Further refinement details for 3. One of the perchlorate anions was modelled as disordered over two positions with their relative occupancies refined freely. Its geometry was restrained to be tetrahedral, with $\mathrm{Cl} \cdots \mathrm{O} 1,2-$ and $\mathrm{O} \cdots \mathrm{Cl} \cdots \mathrm{O}$ 1,3-distances tied to a free variable which was also refined. Both the acetonitrile molecules in the structure were found to be disordered. Their geometries were fixed by restraining both 1,2- and 1,3-distances to the values obtained from Cambridge Structural Database. ${ }^{25}$ One of them was modelled with halfoccupancy due to the disorder being around the inversion center, while the other one was modelled as two disorder components whose relative occupancies were allowed to refine freely. Restraints were also applied to the anisotropic displacement parameters of the disordered parts. Some reflections were obscured by the beam stop and were thus omitted from the refinement.

Further refinement details for 5. The anisotropic displacement parameters of the disordered parts had to be restrained. Some large residual electron density peaks still remained around the platinum and iodine atoms.

\section{Computational details}

The geometry of $\mathbf{L}$ was optimized using the PBE1PBE density functional ${ }^{26}$ together with Ahlrichs' TZVP basis sets. ${ }^{27}$ Calculations were performed for the molecular ground state as well as for the first excited singlet state within the TD-DFT formalism. ${ }^{28}$ Vibrational frequencies were calculated using analytical (ground state) and numerical (excited state) methods to ensure that the stationary points correspond to true minima on the potential energy surface. The polarizable continuum model was used for the treatment of solvent effects. $^{29}$ Vertical excitations/emissions with linear response solvation were considered without state-specific treatment of the solvent reaction field. Single point TD-DFT calculation was also performed for the complex 2 using crystal structure geometry and polarizable continuum model for the treatment of solvent (dichloromethane) effects. All calculations were done with the Gaussan09 program package; ${ }^{30}$ for visualization of optimized geometries and molecular orbitals, the program GaussView was employed. ${ }^{31}$

\section{Results and discussion}

The monoterpyridine ligand $\mathbf{L}$ was prepared via Sonogashira cross-coupling reaction between 4'-(4-bromophenyl)$2,2^{\prime}: 6^{\prime}, 2^{\prime \prime}$-terpyridine and 4-ethynylanisole in the presence of $\mathrm{Pd}\left(\mathrm{PPh}_{3}\right)_{4} / \mathrm{CuI}$ as a catalyst (Scheme 1$)$. Metal (M) complexes of $\mathbf{L}$ were then synthesized (Scheme 2 ) in order to examine the binding of the ligand to different metal centers as well as to study the influence of metal coordination on the observed 
photophysical properties. The $\mathrm{Fe}(\mathrm{II}), \mathrm{Zn}(\mathrm{II})$, and $\mathrm{Cd}(\mathrm{II})$ complexes 1-3 were obtained in $79-90 \%$ yield by reacting the tridentate ligand $\mathbf{L}$ with appropriate metal salts in 2:1 ratio. The

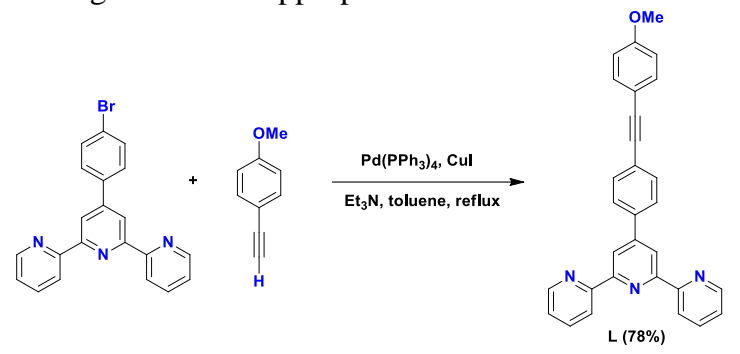

Scheme 1 Synthesis of the terpyridine ligand $\mathbf{L}$.

$\mathrm{Ru}(\mathrm{II})$ complex $\mathbf{4}$ was synthesized by the stepwise addition of $\mathbf{L}$ to the metal center. The 1:1 reaction of $\mathbf{L}$ with $\mathrm{RuCl}_{3} \cdot 3 \mathrm{H}_{2} \mathrm{O}$ in methanol afforded $\left[\mathrm{RuCl}_{3} \mathbf{L}\right]$ which could be further reacted with another equivalent of $\mathbf{L}$ in methanol and in the presence of 4-ethylmorpholine as a reducing agent. Treatment of this solution with excess of ammonium hexafluorophosphate (in water) afforded the complex $\mathbf{4}$ as a bright red solid in 59\% yield. The complex 5 was obtained in $79 \%$ yield by heating a chloroform solution containing trimethylplatinum(IV) iodide and $\mathbf{L}$ in $1: 1$ ratio.

The electrospray ionization mass spectra (ESI-MS) for the bis-ligand complexes 1-4 were consistent with the proposed $\left[\mathrm{ML}_{2}\right](\mathrm{X})_{2}$ formulation $(\mathrm{X}=$ anion); all the complexes exhibited base peaks for the parent ion $\left[\mathrm{ML}_{2}\right]^{2+}$ as well as peaks for singly charged ions $\left[\mathrm{ML}_{2}+\mathrm{X}\right]^{+}$. The ESI-MS analysis of $\mathbf{5}$ showed that the most abundant $\mathrm{m} / \mathrm{z}$, value corresponds to the loss of iodide, giving $\left[\mathrm{PtMe}_{3} \mathbf{L}\right]^{+}$. In addition, the isotope patterns observed for each of the complexes 1-5 were consistent with those calculated for the formulated species.

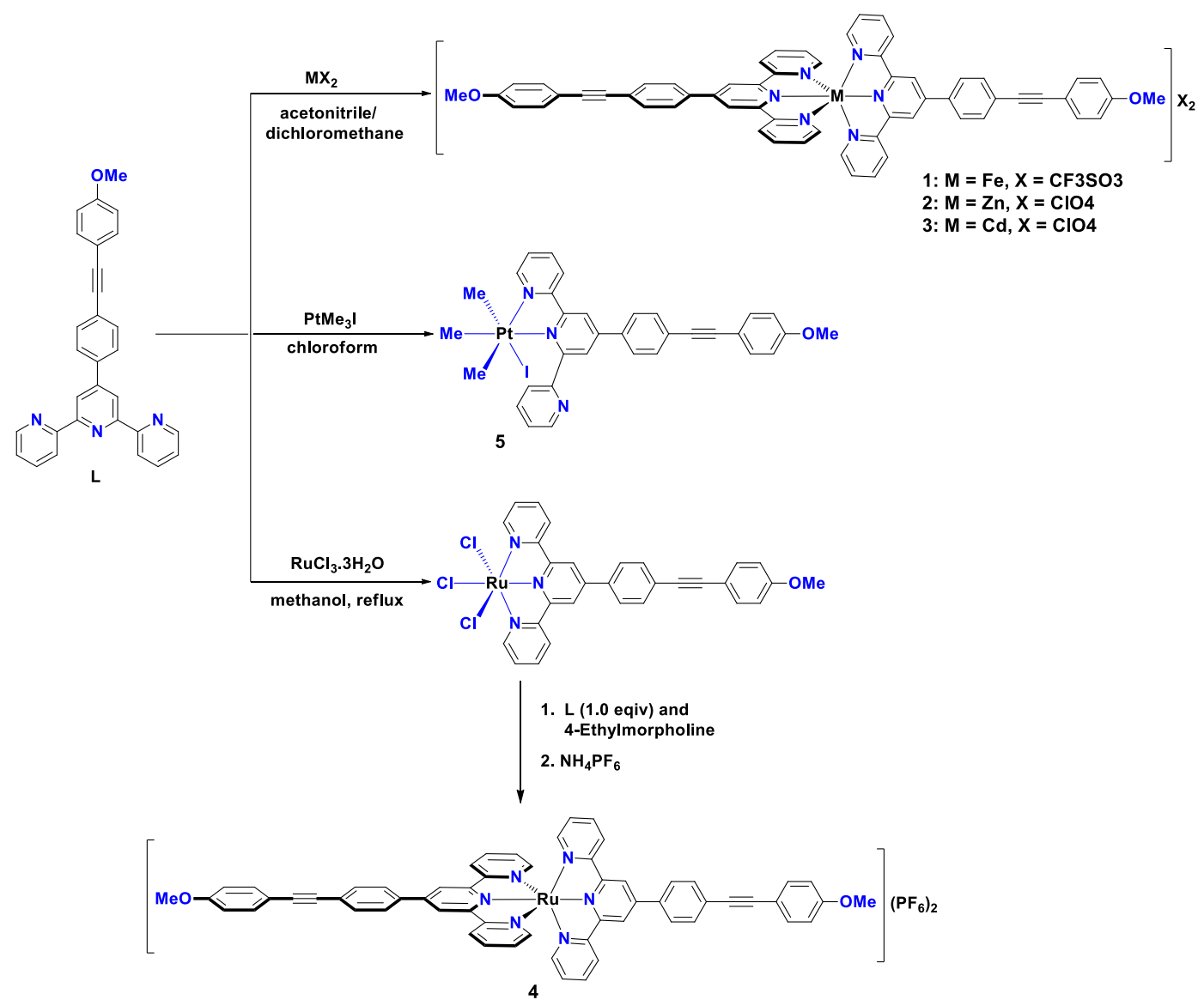

Scheme 2 Synthesis of complexes 1-5.

\section{${ }^{1}$ H NMR spectroscopy}

The room temperature ${ }^{1} \mathrm{H}$ NMR spectra of complexes 1-4 (in $\mathrm{CD}_{3} \mathrm{CN}$ ) are sharp, well resolved and show only one set of signals for the $2,2^{\prime}: 6^{\prime}, 2^{\prime \prime}$-terpyridine domain. This indicates that the terpyridine ligands coordinate to the metal centers in symmetric tridentate fashion. In contrast, the ${ }^{1} \mathrm{H}$ NMR spectrum of complex 5 (in $\mathrm{CD}_{2} \mathrm{Cl}_{2}$ ) is severely broadened at room temperature, indicating the presence of a dynamic process with an exchange rate faster than the NMR timescale. A well resolved spectrum of $\mathbf{5}$ could, however, be obtained upon cooling the sample to $-60{ }^{\circ} \mathrm{C}$ (see ESI $\dagger$ ).

The platinum-methyl region of the low-temperature ${ }^{1} \mathrm{H}$ NMR spectrum of $\mathbf{5}$ is comprised of three signals, each with two satellites due to ${ }^{195} \mathrm{Pt}-\mathrm{H}$ scalar coupling, consistent with the presence of three non-equivalent methyl groups: two in equatorial $\left(\mathrm{Me}_{\mathrm{A}}\right.$ and $\left.\mathrm{Me}_{\mathrm{B}}\right)$ and one in axial $\left(\mathrm{Me}_{\mathrm{C}}\right)$ environment (Fig. 1). This indicates that the terpyridine ligand in $\mathbf{5}$ is coordinated in bidentate fashion and that the ligand oscillates between equivalent bonding modes at higher temperatures. Although similar bidentate coordination has been reported 
before for the $\mathrm{Pt}(\mathrm{IV})$ complexes $\mathrm{PtMe}_{3} \mathrm{X}$ (terpy) $(\mathrm{X}=\mathrm{Cl}$, I; terpy $=2,2^{\prime}: 6^{\prime}, 2^{\prime \prime}$-terpyridine $),{ }^{32}$ the related $\left[\mathrm{PtCl}_{3}\left({ }^{\mathrm{t}} \mathrm{Bu} 3\right.\right.$ terpy $\left.)\right] \mathrm{Cl} \quad{ }^{\mathrm{t}} \mathrm{Bu}_{3}$ terpy $=4,4^{\prime}, 4^{\prime \prime}$-tri-tert-butyl$2,2^{\prime}: 6^{\prime}, 2^{\prime \prime}$-terpyridine) salt contains a cation in which the ligand chelates the metal in tridentate fashion. ${ }^{33}$ The low temperature ${ }^{1} \mathrm{H}$ NMR spectrum of $\mathbf{5}$ also shows ten signals for the hydrogen nuclei of the terpyridine moiety, which further supports the bidentate binding mode. The ${ }^{2} J_{\mathrm{Pt}-\mathrm{H}}$ coupling constant observed for the methyl group trans to the central pyridyl ring $\left(\mathrm{Me}_{\mathrm{B}}\right)$ is greater than that for the methyl group trans to the terminal pyridyl ring $\left(\mathrm{Me}_{\mathrm{A}}\right)$, suggesting that the central pyridinic nitrogen atom exerts greater trans influence and should therefore have a longer $\mathrm{Pt}-\mathrm{N}$ bond (Table 2).

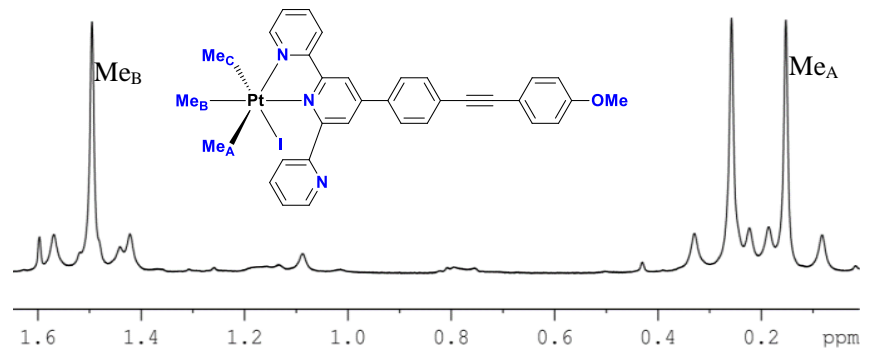

Fig. 1 Platinum-methyl region in the $500 \mathrm{MHz}{ }^{1} \mathrm{H}$ NMR spectrum of complex 5 in $\mathrm{CD}_{2} \mathrm{Cl}_{2}$ at $-60{ }^{\circ} \mathrm{C}$.

\section{Crystallographic investigations}

The structure of the ligand $\mathbf{L}$ : The monoterpyridine ligand $\mathbf{L}$ was crystallized as yellowish-orange crystals upon slow diffusion of chloroform into its methanol solution at room temperature. X-ray crystallographic data and structural refinement parameters of $\mathbf{L}$ are reported in Table 1. Selected bond lengths and angles are shown in Table 2.

The ligand $\mathbf{L}$ crystallizes in the monoclinic $P 21 / c$ space group. The crystal structure of $\mathbf{L}$ (Fig. 2) shows that the pyridinic nitrogen atoms on the terpyridine moiety adopt a trans arrangement about the bonds $\mathrm{C} 6-\mathrm{C} 7$ and $\mathrm{C} 9-\mathrm{C} 13$. Such configuration is commonly found in the solid state structures of terpyridines as it minimizes the unfavorable electrostatic and Pauli repulsion between the nitrogen atoms. ${ }^{34}$ The interannular $\mathrm{C}-\mathrm{C}$ bond lengths [1.487(2)-1.491(2) $\AA$ ] are comparable with those of the previously reported $2,2^{\prime}: 6^{\prime}, 2^{\prime \prime}$-terpyridines; the $\mathrm{C}-\mathrm{C}[1.3342(18)-1.3503(18) \AA]$ and $\mathrm{C}-\mathrm{N}[1.375(2)-1.395(2)$ $\AA]$ bond lengths in the pyridyl and the $\mathrm{C}-\mathrm{C}$ bond lengths $[1.378(2)-1.400(2) \AA]$ in the phenyl rings are also within the expected ranges. ${ }^{34-35}$ The structure of the ligand is planar with the exception of the aryl ring linking the terpyridine and ethynylanisole moiety that is slightly $\left(20.17(5)^{\circ}\right)$ tilted from the mean plane of the molecule. The geometry around the $\mathrm{C} \equiv \mathrm{C}$ triple bond is essentially linear as evidenced by the bond angles $\angle(\mathrm{C} 22-\mathrm{C} 25-\mathrm{C} 26)=175.14(16)^{\circ}$ and $\angle(\mathrm{C} 25-\mathrm{C} 26-\mathrm{C} 27)=$ $178.94(16)^{\circ}$.

The packing of $\mathbf{L}$ within the crystal lattice is dominated by weak $\pi \cdots \pi$ and $\mathrm{C}-\mathrm{H} \cdots \mathrm{N} / \mathrm{O}$ interactions. The $\pi \cdots \pi$ interactions between the terminal rings of adjacent terpyridine moieties are $3.270(2)$ and 3.290(2) $\AA$, giving rise to a $\pi$-stacked head-to-tail centrosymmetric dimer arrangement in the solid state (Fig. 3). The dimers are further connected by offset $\pi \cdots \pi$ interactions (closest dimer-to-dimer distance is 3.360(2) $\AA$ ) and the packing is further reinforced by $\mathrm{C}-\mathrm{H} \cdots \mathrm{N}($ pyridyl $)(d(\mathrm{C} \cdots \mathrm{N})=3.415(2)$
$\AA$ and $3.485(2) \AA)$ and $\mathrm{C}-\mathrm{H} \cdots \mathrm{O}\left(\mathrm{CH}_{3}\right)(d(\mathrm{C} \cdots \mathrm{O}=3.238(2) \AA)$ hydrogen bonds between neighboring molecules.

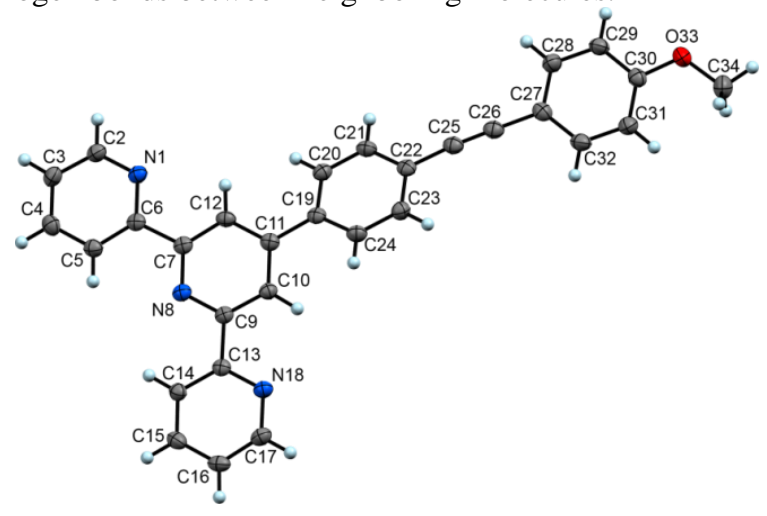

Fig. 2 ORTEP plot of the molecular structure of $\mathbf{L}$ with the atom labelling scheme. Thermal ellipsoids are shown at 50\% probability level.

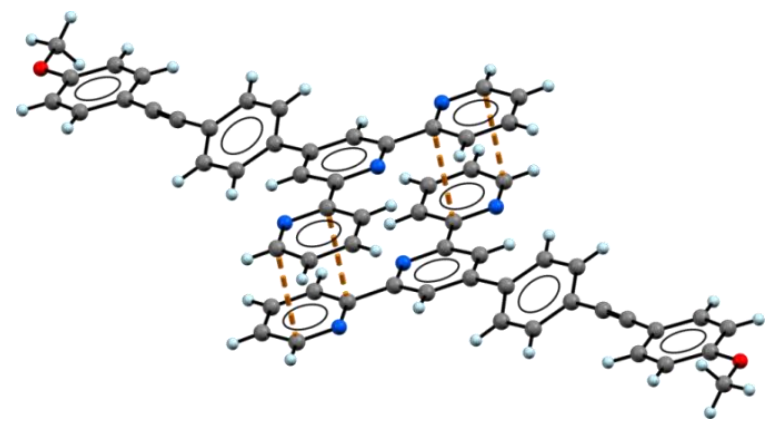

Fig. 3 Centrosymmetric $\pi$-stacked dimer in the crystal structure of $\mathbf{L}$ showing the weak $\pi \cdots \pi$ interactions between the adjacent terpyridine moieties.

The crystal structures of 1-3: Single crystals of $\mathbf{1}$ and $\mathbf{3}$ were obtained by slow diffusion of diisopropyl ether into their acetonitrile solutions at room temperature; a 2:1 mixture of acetonitrile and dichloromethane was used in the case of complex 2. X-ray crystallographic data and structural refinement parameters of the complexes are listed in Table 1, whereas selected bond lengths and angles of the complexes are given in Table 2. Complexes 1-3 all crystallize in the triclinic space group $P 1$. The crystal structures of $\mathbf{2}$ and $\mathbf{3}$ contain molecules of the crystallization solvent (acetonitrile) in the crystal lattice and the crystal structure of $\mathbf{3}$ contains two crystallographically independent cations in the unit cell.

The crystal structure of $\mathbf{1}$ confirms the anticipated 2:1 ligand to metal stoichiometry in the cation. The Fe(II) center shows distorted octahedral geometry in which the two terpyridine ligands occupy mer coordination sites (Fig. 4). The $\mathrm{Fe}-\mathrm{N}$ bond distances involving the central pyridyl ring $[1.879(2)$ and $1.885(2) \AA]$ are significantly shorter than those to the terminal pyridyl rings [1.971(3)-1.988(3) Å] (Table 2), which arises from the restricted bite angle of the terpyridine ligand. As a whole, the $\mathrm{Fe}-\mathrm{N}$ bond distances are comparable with those reported for related $\mathrm{Fe}(\mathrm{II})$-terpyridine complexes. ${ }^{2 \mathrm{~g}}$, 36 The crystal structures of $\mathbf{2}$ and $\mathbf{3}$ show the formation of similar bis-complexes as in the case of $\mathbf{1}$ in which the metal centers (M) have a distorted $\mathrm{MN}_{6}$ core (Fig. 4). All other key bond lengths and angles in 1-3 are similar to those reported for related $\mathrm{Fe}(\mathrm{II})^{2 \mathrm{~g}, 36}$ and $\mathrm{Zn}(\mathrm{II}) / \mathrm{Cd}(\mathrm{II})$-terpyridine complexes. ${ }^{2 \mathrm{c},} 2 \mathrm{~g}$, 37 The $\mathrm{M}-\mathrm{N}$ bond distances increase from $\mathbf{1}$ to $\mathbf{3}$ due to the 
increasing metal size (Table 2) which also leads to a decrease in the bite angle of the terpyridine ligand. The cations in 1-3 are all slightly bent around the $\mathrm{C} \equiv \mathrm{C}$ triple bond, similarly to the free ligand $\mathbf{L}$, but the relative orientation of the aryl rings in the diphenylacetylene moiety differs significantly from the mean plane of the terpyridine framework with no regularity in the observed twist angles.

The crystal structure of 5: In order to confirm the bidentate chelate nature of the terpyridine ligand in $\mathbf{5}$, crystal structure of the complex was sought. Yellow crystals of $\mathbf{5}$ were obtained by slow diffusion of $n$-hexane into its dichloromethane solution at room temperature. $\mathrm{X}$ ray crystallographic data and structural refinement parameters for $\mathbf{5}$ are reported in Table 1, whereas selected bond lengths and angles are given in Table 2.

Complex 5 crystallizes in the monoclinic $P 2{ }_{1} / c$ space group and with adventitious solvent molecules (dichloromethane) in the crystal lattice. The asymmetric unit consists of two crystallographically independent complexes in which the Pt(IV) centers are hexacoordinated by three methyl groups in fac arrangement, an iodine atom, and the terpyridine ligand in a bidentate binding mode (Fig. 5). The $\mathrm{Pt}-\mathrm{N}$ bond distance involving the central pyridyl ring is significantly (> $0.1 \AA$ ) longer than the $\mathrm{Pt}-\mathrm{N}$ bond of the terminal pyridyl ring (Table 2) as predicted from the ${ }^{2} J_{\mathrm{Pt}-\mathrm{H}}$ coupling constants in the low temperature ${ }^{1} \mathrm{H}$ NMR data. As a whole, the key bond lengths and bond angles of $\mathbf{5}$ are very much comparable to that reported for the related complex $\left[\mathrm{PtMe}_{3} \mathrm{I}(\right.$ terpy)$) .{ }^{32 \mathrm{a}}$ With $\mathbf{L}$ acting as a bidentate ligand in $\mathbf{5}$, significant deviation from planarity is observed even for its terpyridine moiety. The two coordinated pyridyl rings are twisted from planarity by $19.1(4)^{\circ}$ while the angle between the central and the non-coordinated pyridyl ring is significantly larger, $48.3(5)^{\circ}$ (the corresponding torsion angles are $14.4(5)^{\circ}$ and $40.6(5)^{\circ}$ in the other crystallographically independent molecule in the unit cell). The packing of $\mathbf{5}$ is influenced by weak intra- and intermolecular hydrogen bonding involving the non-coordinated pyridyl ring, the methoxy substituent, the iodide ligand as well as the solvent molecules trapped in the crystal lattice.

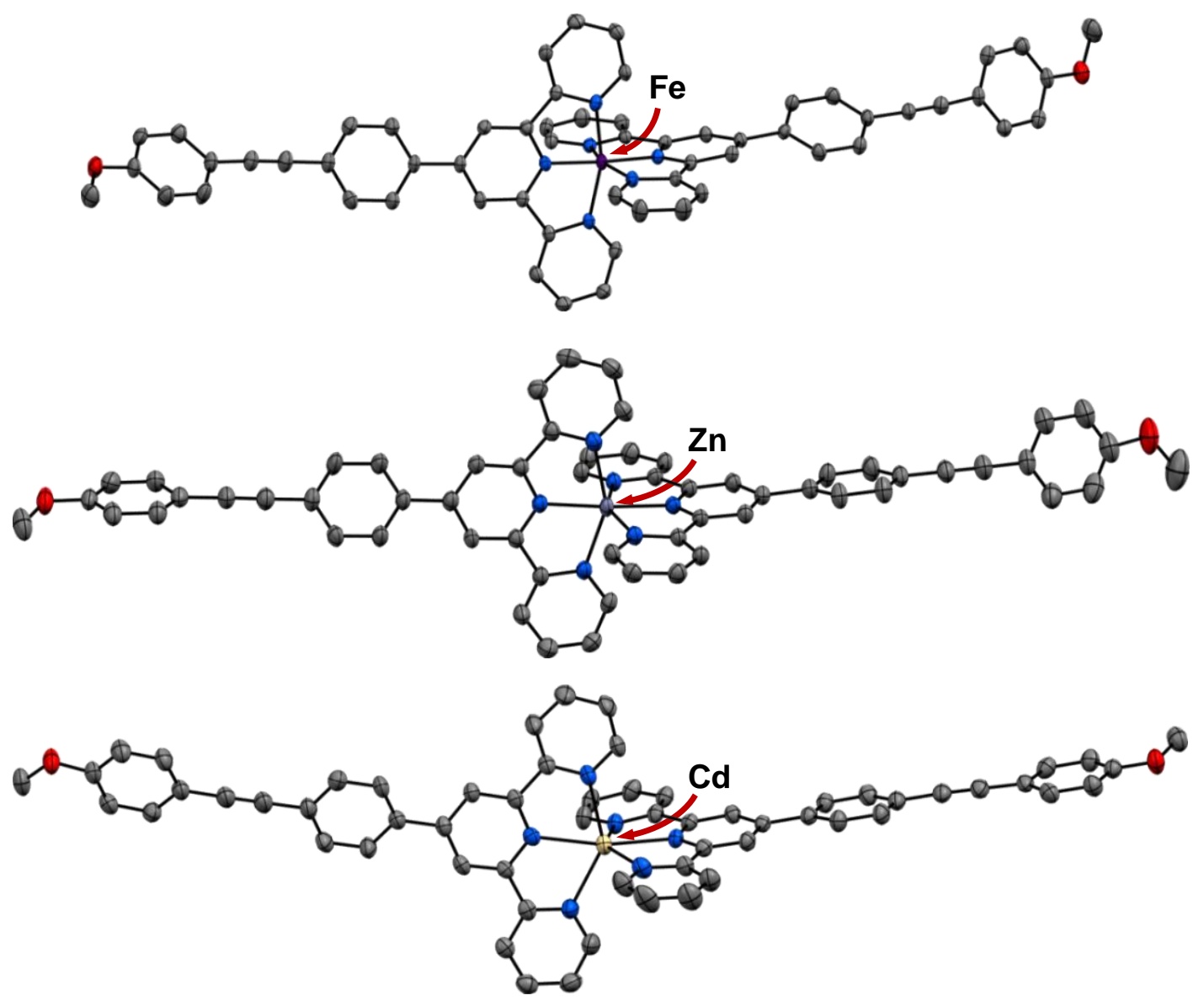

Fig. 4 ORTEP plots of the cations present in the lattices of complexes $\mathbf{1}$ (top), $\mathbf{2}$, and $\mathbf{3}$ (bottom). Thermal ellipsoids are drawn at the $50 \%$ level. Hydrogen atoms, anions, and solvent molecules are omitted for clarity. In the case of $\mathbf{3}$, only one of the two crystallographically independent cations is shown. 


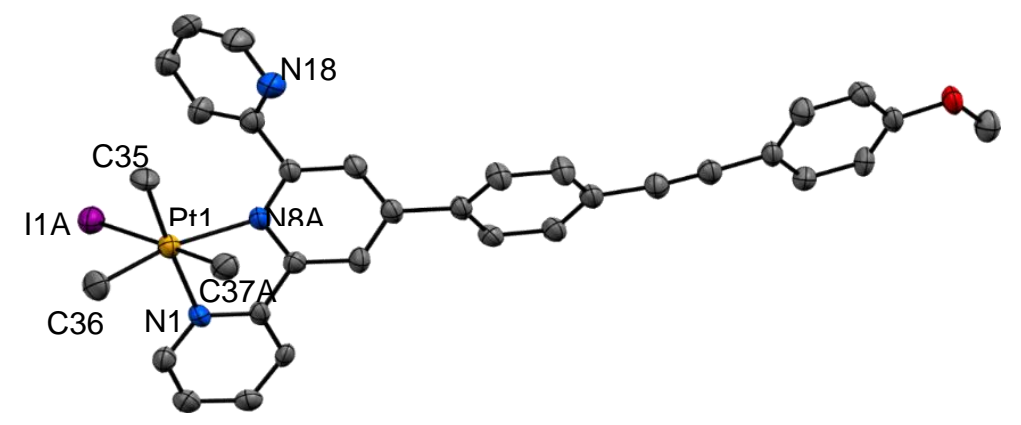

Fig. 5 ORTEP plot of 5 . Thermal ellipsoids are drawn at the $50 \%$ level and atom labelling is shown only for nitrogen atoms and the atoms directly bound to the platinum center. Hydrogen atoms and solvent molecules are omitted for clarity and only one of the two crystallographically independent molecules is shown.

Table 1 Crystallographic data for the ligand $\mathbf{L}$ and the metal complexes 1-3 and $\mathbf{5}$.

\begin{tabular}{|c|c|c|c|c|c|}
\hline & $\mathbf{L}$ & 1 & 2 & 3 & 5 \\
\hline CCDC No. & 941619 & 1008273 & 1008274 & 1008275 & 1008276 \\
\hline empirical formula & $\mathrm{C}_{30} \mathrm{H}_{21} \mathrm{~N}_{3} \mathrm{O}$ & $\mathrm{C}_{62} \mathrm{H}_{42} \mathrm{~F}_{6} \mathrm{FeN}_{6} \mathrm{O}_{8} \mathrm{~S}_{2}$ & $\begin{array}{l}\mathrm{C}_{63.83} \mathrm{H}_{47.83} \mathrm{Cl}_{2.34} \mathrm{~N}_{7.83} \mathrm{O}_{10} \\
\mathrm{Zn}\end{array}$ & $\begin{array}{l}\mathrm{C}_{61.50} \mathrm{H}_{44.25} \mathrm{CdCl}_{2} \mathrm{~N}_{6.75} \\
\mathrm{O}_{10}\end{array}$ & $\mathrm{C}_{34} \mathrm{H}_{32} \mathrm{Cl}_{2} \mathrm{IN}_{3} \mathrm{OPt}$ \\
\hline $\mathrm{M}_{\mathrm{w}} / \mathrm{g}$ & 439.50 & 1232.98 & 1232.65 & 1221.08 & 891.51 \\
\hline $\mathrm{T} / \mathrm{K}$ & $123.0(1)$ & $123.0(1)$ & $123.0(1)$ & $123.0(1)$ & $123.0(1)$ \\
\hline$\lambda / \AA$ & 0.71073 & 0.71073 & 1.54184 & 0.71073 & 1.54184 \\
\hline $\begin{array}{l}\text { crystal color, } \\
\text { shape }\end{array}$ & $\begin{array}{l}\text { Orange-yellow, } \\
\text { block }\end{array}$ & purple, block & yellow, plate & yellow, plate & yellow, lath \\
\hline crystal size $/ \mathrm{mm}^{3}$ & $0.60 \times 0.50 \times 0.50$ & $0.25 \times 0.15 \times 0.10$ & $0.36 \times 0.11 \times 0.04$ & $0.60 \times 0.30 \times 0.05$ & $0.36 \times 0.12 \times 0.04$ \\
\hline crystal system & Monoclinic & triclinic & Triclinic & triclinic & Monoclinic \\
\hline space group & $P 2_{1} / c$ & $P \overline{1}$ & $P \overline{1}$ & $P \overline{1}$ & $P 2_{1} / c$ \\
\hline 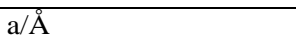 & $16.6843(5)$ & $11.2130(3)$ & $9.0650(3)$ & $13.9688(2)$ & $10.96168(15)$ \\
\hline $\mathrm{b} / \AA$ & $8.3034(3)$ & $13.3540(4)$ & $13.7517(7)$ & $17.2312(2)$ & $23.2974(4)$ \\
\hline $\mathrm{c} / \AA$ & $16.3540(4)$ & $19.9336(7)$ & $23.0439(9)$ & $25.2477(4)$ & $25.7681(5)$ \\
\hline$\alpha /{ }^{\circ}$ & 90 & $79.9930(16)$ & $84.220(4)$ & $102.2197(7)$ & 90 \\
\hline$\beta /{ }^{\circ}$ & $103.3099(16)$ & $87.9424(18)$ & $79.057(3)$ & $99.7574(7)$ & $99.2317(15)$ \\
\hline$\gamma /{ }^{\circ}$ & 90 & $65.3545(16)$ & $87.837(4)$ & $109.5050(8)$ & 90 \\
\hline $\mathrm{V} / \AA^{3}$ & $2204.77(12)$ & $2669.42(15)$ & $2805.6(2)$ & $5405.00(13)$ & $6495.39(19)$ \\
\hline $\mathrm{Z}$ & 4 & 2 & 2 & 4 & 8 \\
\hline$\rho_{\mathrm{c}} / \mathrm{gcm}^{-3}$ & 1.324 & 1.534 & 1.459 & 1.501 & 1.823 \\
\hline$\mu / \mathrm{mm}^{-1}$ & 0.082 & 0.448 & 2.212 & 0.572 & 17.302 \\
\hline $\mathrm{F}(000)$ & 920 & 1264 & 1271 & 2490 & 3440 \\
\hline$\theta$ range $/^{\circ}$ & 2.51 to 25.25 & 2.08 to 25.25 & 3.23 to 67.75 & 2.29 to 25.25 & 3.48 to 67.73 \\
\hline $\begin{array}{l}\text { completeness } \\
\text { to } \theta_{\text {full }}\end{array}$ & $99.3 \%$ & $99.7 \%$ & $98.5 \%$ & $99.7 \%$ & $98.7 \%$ \\
\hline reflections collected & 9296 & 21832 & 15789 & 43577 & 20527 \\
\hline $\begin{array}{l}\text { independent } \\
\text { reflections }\end{array}$ & $\begin{array}{l}3948 \\
{[\mathrm{R}(\mathrm{int})=0.0261]}\end{array}$ & $\begin{array}{l}9631 \\
{[\mathrm{R}(\mathrm{int})=0.0494]}\end{array}$ & $\begin{array}{l}10005 \\
{[\mathrm{R}(\mathrm{int})=0.0340]}\end{array}$ & $\begin{array}{l}19498 \\
{[\mathrm{R}(\mathrm{int})=0.0373]}\end{array}$ & $\begin{array}{l}11610 \\
{[\mathrm{R}(\mathrm{int})=0.0288]}\end{array}$ \\
\hline absorption correction & multi-scan & multi-scan & multi-scan & multi-scan & $\begin{array}{l}\text { numerical } \\
\text { (gaussian) }\end{array}$ \\
\hline $\begin{array}{l}\text { max. and } \\
\text { min. transmission }\end{array}$ & 0.7457 and 0.6075 & 0.7457 and 0.6008 & 1.0000 and 0.8781 & 0.7457 and 0.5934 & 0.6490 and 0.0810 \\
\hline refinement method & $\begin{array}{ll}\text { full-matrix } & \text { least } \\
\text { squares on } \mathrm{F}^{2} & \end{array}$ & $\begin{array}{ll}\text { full-matrix } & \text { least } \\
\text { squares on } \mathrm{F}^{2} & \end{array}$ & $\begin{array}{l}\text { full-matrix least squares } \\
\text { on } \mathrm{F}^{2}\end{array}$ & $\begin{array}{ll}\text { full-matrix } & \text { least } \\
\text { squares on } \mathrm{F}^{2} & \end{array}$ & $\begin{array}{ll}\text { full-matrix } & \text { least } \\
\text { squares on } \mathrm{F}^{2}\end{array}$ \\
\hline $\begin{array}{l}\text { data/restraints/ } \\
\text { parameters }\end{array}$ & $3948 / 0 / 308$ & $9377 / 0 / 768$ & $10005 / 506 / 891$ & $19504 / 344 / 1559$ & $11610 / 42 / 765$ \\
\hline $\begin{array}{l}\text { goodness-of-fit } \\
\text { on } \mathrm{F}^{2}\end{array}$ & 1.047 & 1.015 & 1.033 & 1.020 & 1.086 \\
\hline $\begin{array}{l}\text { final } \mathrm{R} \text { indices } \\
{[\mathrm{I}>2 \sigma(\mathrm{I})]}\end{array}$ & $\begin{array}{l}\mathrm{R} 1=0.0401, \\
\mathrm{wR} 2=0.0968\end{array}$ & $\begin{array}{l}\mathrm{R} 1=0.0556, \\
\mathrm{wR} 2=0.1082\end{array}$ & $\begin{array}{l}\mathrm{R} 1=0.0612, \\
\mathrm{wR} 2=0.1667\end{array}$ & $\begin{array}{l}\mathrm{R} 1=0.0526, \\
\mathrm{wR} 2=0.1130\end{array}$ & $\begin{array}{l}\mathrm{R} 1=0.0570 \\
\mathrm{wR} 2=0.1424\end{array}$ \\
\hline $\begin{array}{l}\mathrm{R} \text { indices } \\
\text { (all data) }\end{array}$ & $\begin{array}{l}\mathrm{R} 1=0.0546 \\
\mathrm{wR} 2=0.1054\end{array}$ & $\begin{array}{l}\mathrm{R} 1=0.0935 \\
\mathrm{wR} 2=0.1257\end{array}$ & $\begin{array}{l}\mathrm{R} 1=0.0760 \\
\mathrm{wR} 2=0.1829\end{array}$ & $\begin{array}{l}\mathrm{R} 1=0.0798 \\
\mathrm{wR} 2=0.1277\end{array}$ & $\begin{array}{l}\mathrm{R} 1=0.0631 \\
\mathrm{wR} 2=0.1470\end{array}$ \\
\hline $\begin{array}{l}\text { largest diff. peak and } \\
\text { hole }\left(\mathrm{e}^{-3}\right)\end{array}$ & 0.167 and -0.156 & 0.423 and -0.379 & 0.727 and -0.778 & 0.822 and -0.780 & 2.284 and -1.795 \\
\hline
\end{tabular}


Table 2 Selected bond lengths $(\AA)$ and angles $\left(^{\circ}\right)$ for the ligand $\mathbf{L}$ and the metal complexes 1-3 and $\mathbf{5}$.

\begin{tabular}{|c|c|c|c|c|c|}
\hline \multicolumn{6}{|l|}{ Ligand L } \\
\hline $\mathrm{C} 2-\mathrm{N} 1$ & $1.3342(18)$ & C7-N8 & $1.3430(18)$ & C13-N18 & $1.3490(18)$ \\
\hline C6-N1 & $1.3503(18)$ & C9-N8 & $1.3451(17)$ & C17-N18 & $1.3403(19)$ \\
\hline C6-C7 & $1.4865(19)$ & C9-C13 & $1.4904(19)$ & C11-C19 & $1.4875(19)$ \\
\hline $\mathrm{C} 22-\mathrm{C} 25$ & $1.436(2)$ & $\mathrm{C} 25-\mathrm{C} 26$ & $1.201(2)$ & $\mathrm{C} 26-\mathrm{C} 27$ & $1.434(2)$ \\
\hline $\mathrm{C} 2-\mathrm{C} 3$ & $1.382(2)$ & C4-C5 & $1.383(2)$ & C7-C12 & $1.3937(19)$ \\
\hline $\mathrm{C} 3-\mathrm{C} 4$ & $1.387(2)$ & C5-C6 & $1.393(2)$ & C9-C10 & $1.3850(19)$ \\
\hline C10-C11 & $1.395(2)$ & C30-O33 & $1.3648(17)$ & C34-O33 & 1.4278(19) \\
\hline N1-C2-C3 & 123.94(14) & N1-C6-C5 & $122.12(13)$ & N1-C6-C7 & 116.11(12) \\
\hline N8-C7-C12 & $122.65(13)$ & N8-C7-C6 & $116.58(12)$ & N8-C9-C10 & $122.68(13)$ \\
\hline N8-C9-C13 & $116.38(12)$ & N18-C13-C14 & $122.25(13)$ & N18-C13-C9 & $116.93(12)$ \\
\hline N18-C17-C16 & $123.83(14)$ & C2-N1-C6 & $117.57(12)$ & C7-N8-C9 & $117.78(12)$ \\
\hline C17-N18-C13 & $117.25(12)$ & C30-O33-C34 & $118.36(12)$ & O33-C30-C31 & $124.72(13)$ \\
\hline O33-C30-C29 & $115.36(13)$ & C26-C25-C22 & $175.13(16)$ & C25-C26-C27 & $178.94(16)$ \\
\hline \multicolumn{2}{|l|}{ Complex 1} & \multicolumn{2}{|l|}{ Complex 2} & \multicolumn{2}{|l|}{ Complex $3^{a}$} \\
\hline Fe1-N1A & $1.974(3)$ & Zn1-N1A & $2.178(3)$ & Cd1A-N1A & $2.325(4)$ \\
\hline Fe1-N1B & $1.988(3)$ & Zn1-N1B & $2.185(3)$ & Cd1A-N1B & $2.345(4)$ \\
\hline Fe1-N8A & $1.879(2)$ & Zn1-N8A & 2.071(3) & Cd1A-N8A & $2.322(3)$ \\
\hline Fe1-N8B & $1.885(2)$ & Zn1-N8B & $2.070(3)$ & Cd1A-N8B & $2.295(3)$ \\
\hline Fe1-N18A & $1.971(3)$ & Zn1-N18A & $2.197(3)$ & Cd1A-N18A & $2.374(3)$ \\
\hline Fe1-N18B & $1.981(3)$ & Zn1-N18B & $2.219(3)$ & Cd1A-N18B & $2.340(4)$ \\
\hline N1A-Fe1-N8A & $80.90(11)$ & N1A-Zn1-N8A & $75.55(10)$ & N1A-Cd1A-N8A & $70.21(13)$ \\
\hline N1A-Fe1-N18A & $161.60(11)$ & N1A- Zn1-N18A & $150.71(10)$ & N1A-Cd1A-N18A & $138.91(12)$ \\
\hline N1A-Fe1-N1B & $89.81(12)$ & N1A-Zn1-N1B & $88.55(10)$ & N1A-Cd1A-N1B & $98.79(13)$ \\
\hline N1A-Fe1-N8B & $97.99(11)$ & N1A-Zn1-N8B & $108.59(10)$ & N1A-Cd1A-N8B & $114.53(12)$ \\
\hline N1A-Fe1-N18B & $93.37(12)$ & N1A-Zn1-N18B & $99.47(11)$ & N1A-Cd1A-N18B & $96.05(13)$ \\
\hline N8A-Fe1-N18A & $80.87(11)$ & N8A-Zn1-N18A & $75.49(10)$ & N8A-Cd1A-N18A & $68.87(11)$ \\
\hline N8A-Fe1-N1B & $95.66(12)$ & N8A-Zn1-N1B & $107.01(10)$ & N8A-Cd1A-N1B & $117.49(12)$ \\
\hline N8A-Fe1-N8B & $176.51(13)$ & N8A-Zn1-N8B & 175.11(11) & N8A-Cd1A-N8B & $170.93(12)$ \\
\hline N8A-Fe1-N18B & $102.66(12)$ & N8A-Zn1-N18B & $102.05(10)$ & N8A-Cd1A-N18B & $101.93(12)$ \\
\hline N18A-Fe1-N1B & $94.42(12)$ & N18A-Zn1-N1B & $95.78(10)$ & N18A-Cd1A-N1B & $102.96(13)$ \\
\hline N18A-Fe1-N8B & $100.36(11)$ & N18A-Zn1-N8B & $100.55(10)$ & N18A-Cd1A-N8B & $105.54(11)$ \\
\hline N18A-Fe1-N18B & $88.22(12)$ & N18A-Zn1-N18B & $90.70(11)$ & N18A-Cd1A-N18B & $88.83(12)$ \\
\hline N1B-Fe1-N8B & $81.01(12)$ & N1B-Zn1-N8B & $76.04(10)$ & N1B-Cd1A-N8B & $70.23(12)$ \\
\hline N1B-Fe1-N18B & $161.68(10)$ & N1B-Zn1-N18B & $150.94(10)$ & N1B-Cd1A-N18B & $140.54(12)$ \\
\hline N8B-Fe1-N18B & $80.68(12)$ & N8B-Zn1-N18B & $74.93(10)$ & N8B-Cd1A-N18B & $70.33(12)$ \\
\hline $\mathrm{C} 22 \mathrm{~A}-\mathrm{C} 25 \mathrm{~A}-\mathrm{C} 26 \mathrm{~A}$ & $172.3(4)$ & C22A-C25A-C26A & $174.4(5)$ & C22A-C25A-C26A & $174.7(6)$ \\
\hline C25A-C26A-C27A & $176.5(4)$ & C25A-C26A-C27A & $176.4(5)$ & C25A-C26A-C27A & $177.6(6)$ \\
\hline C22B-C25B-C26B & 174.7(4) & C22B-C25B-C26B & $179.2(4)$ & $\mathrm{C} 22 \mathrm{~B}-\mathrm{C} 25 \mathrm{~B}-\mathrm{C} 26 \mathrm{~B}$ & $174.5(5)$ \\
\hline C25B-C26B-C27B & $175.9(4)$ & C25B-C26B-C27B & $178.3(4)$ & C25B-C26B-C27B & $178.3(5)$ \\
\hline \multicolumn{6}{|l|}{ Complex 5} \\
\hline Pt1A-N1A & $2.151(7)$ & Pt1B-N1B & $2.127(8)$ & Pt1A-I1A & $2.7505(8)$ \\
\hline Pt1A-N8A & $2.252(7)$ & Pt1B-N8B & $2.256(8)$ & Pt1B-I1B & $2.7892(10)$ \\
\hline Pt1A-C35A & $2.061(11)$ & Pt1A-C36A & $2.054(9)$ & Pt1A-C37A & $2.069(10)$ \\
\hline Pt1B-C35B & $2.046(12)$ & Pt1B-C36B & $2.048(12)$ & Pt1B-C37B & $2.135(13)$ \\
\hline N1A-Pt1A-N8A & $76.2(2)$ & N1A-Pt1A-I1A & 87.87(19) & N8A-Pt1A-I1A & 96.24(18) \\
\hline C35A-Pt1A-N1A & $176.9(3)$ & C36A-Pt1A-N1A & $95.4(4)$ & C37A-Pt1A-N1A & $92.7(3)$ \\
\hline C35A-Pt1A-N8A & 101.3(3) & C36A-Pt1A-N8A & $168.5(3)$ & C37A-Pt1A-N8A & $85.6(3)$ \\
\hline C35A-Pt1A-I1 A & $94.3(3)$ & C36A-Pt1A-I1A & 91.2(3) & C37A-Pt1A-I1A & 178.2(3) \\
\hline C36A-Pt1A-C35A & $86.8(4)$ & C36A-Pt1A-C37A & $87.1(4)$ & C35A-Pt1A-C37A & $85.2(4)$ \\
\hline N1B-Pt1B-N8B & $76.1(3)$ & N1B-Pt1B-I1B & $86.6(2)$ & N8B-Pt1B-I1B & 95.65(19) \\
\hline C35B-Pt1B-N1B & $175.9(5)$ & C36B-Pt1B-N1B & $97.4(5)$ & N1B-Pt1B-C37B & $92.2(4)$ \\
\hline C35B-Pt1B-N8B & $102.3(4)$ & C36B-Pt1B-N8B & $171.7(4)$ & C37B-Pt1B-N8B & $86.1(3)$ \\
\hline
\end{tabular}

${ }^{a}$ Data is given for only one of the two crystallographically independent molecules in the unit cell. 


\section{Absorption spectroscopy and DFT calculations}

The room temperature UV-Vis spectrum of $\mathbf{L}$ (in dichloromethane) shows absorption maxima at $322 \mathrm{~nm}$ (extinction coefficient $4.48 \times 10^{4} \mathrm{M}^{-1} \mathrm{~cm}^{-1}$ ) along with a shoulder at $298 \mathrm{~nm}$ (extinction coefficient $4.12 \times 10^{4} \mathrm{M}^{-1} \mathrm{~cm}^{-1}$ ) (Fig. 6). The absorption maxima of $\mathbf{L}$ is influenced only marginally by change in solvent polarity (Table 3 , see ESI $\dagger$ ) and is considerably red-shifted compared to that of $4^{\prime}$-phenyl$2,2^{\prime}: 6^{\prime}, 2^{\prime \prime}$-terpyridine (278 $\mathrm{nm}$ in dichloromethane), ${ }^{11 \mathrm{~d}} 4^{\prime}$-(4-

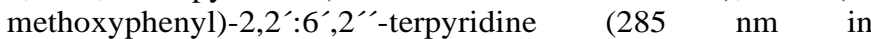
dichloromethane), ${ }^{11 \mathrm{~d}}$ and $4^{\prime}-\left(\left[1,1^{\prime}\right.\right.$-biphenyl $\left.]-4-y 1\right)-2,2^{\prime}: 6^{\prime}, 2^{\prime \prime}-$ terpyridine (289 $\mathrm{nm}$ in ethanol). ${ }^{11 \mathrm{c}}$ That the monoterpyridine ligand $\mathbf{L}$ absorbs at higher wavelength in comparison to the mentioned terpyridines can be explained with the morphology of its frontier orbitals (Fig. 7) and the rigidity of the conjugated linkage between the diphenylacetylene moiety and the central pyridyl ring of the terpyridine fragment. ${ }^{12 \mathrm{a}, 12 \mathrm{~b}}$

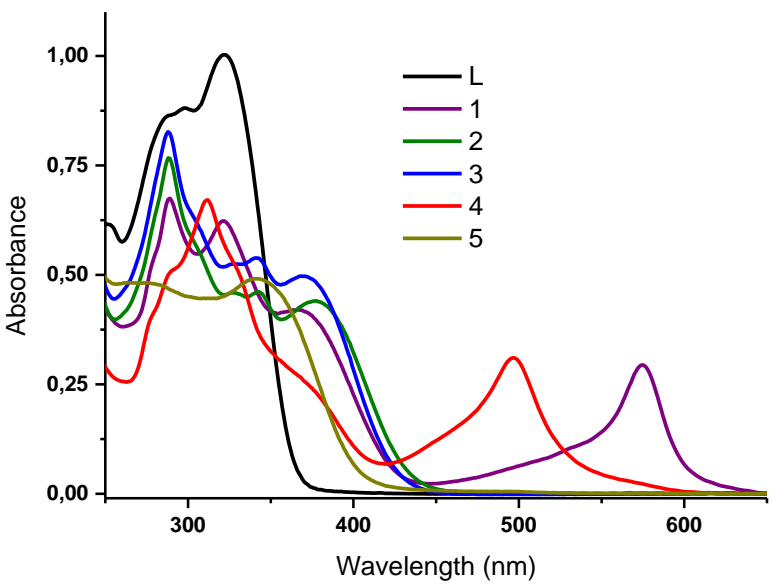

Fig. 6 UV-Vis absorption spectra of the terpyridine ligand $\mathbf{L}$ and its metal complexes 1-5 in dichloromethane $\left(25^{\circ} \mathrm{C}\right)$.

DFT calculations (at the PBE1PBE/TZVP level) were conducted to provide insight into the electronic structure of the ligand $\mathbf{L}$. The optimized structure of $\mathbf{L}$ (see ESI $\dagger$ ) was found to be in very good agreement with the X-ray data, the only exception being the twist angle between the terpyridine and ethynylanisole moieties. This difference can, however, be attributed to the omission of crystal packing interactions in calculations conducted for isolated molecules in the gas phase. The vertical excitation energies of $\mathbf{L}$ were subsequently calculated with time dependent TD-DFT formalism using the optimized molecular coordinates and the PBE1PBE/TZVP functional/basis set combination.

In good agreement with the experimental data (Table 3), the TD-DFT calculation for $\mathbf{L}$ in the gas phase reveals two excitations between 275 and $400 \mathrm{~nm}$ with significant oscillator strengths. The most intense band involves the HOMO $\rightarrow$ LUMO excitation at $347 \mathrm{~nm}$, whereas the other transition appears as a shoulder at $289 \mathrm{~nm}$ and has the biggest contribution form the $\mathrm{HOMO} \rightarrow \mathrm{LUMO}+2$ excitation (see ESI $\dagger$ ). The frontier KohnSham orbitals of $\mathbf{L}$ relevant to the calculated absorption at 347 $\mathrm{nm}$ are shown in Fig. 7. It is immediately evident that the HOMO $\rightarrow$ LUMO transition is clearly of $\pi \rightarrow \pi^{*}$ type and involves an intramolecular transfer of electron density from the diphenylacetylene moiety (HOMO) to the terpyridine framework (LUMO). The HOMO of $\mathbf{L}$ is essentially the HOMO of free 1,2-diphenylacetylene (see ESI $\dagger$ ), whereas the LUMO of $\mathbf{L}$ is a linear combination of orbitals from both the diphenylacetylene and terpyridine fragments. The electronic structure of $\mathbf{L}$ is therefore a hybrid of its constituents, which is clearly reflected in its fluorescence properties that are quite unlike to other monoterpyridine ligands known to date (see below).

Table 3 Photophysical properties of $\mathbf{L}$ in different solvents and in the solid state

\begin{tabular}{|l|l|l|l|l|}
\hline System & $\lambda_{\max }{ }^{\text {abs }}(\mathrm{nm})^{a}$ & $\lambda_{\max }{ }^{\mathrm{em}}(\mathrm{nm})^{b}$ & $\tau_{\mathrm{F}}(\mathrm{ns})^{c}$ & $\Phi_{\mathrm{F}^{d}}$ \\
\hline THF & 324 & 406 & 1.24 & 0.66 \\
\hline $\mathrm{DCM}$ & 322 & 411 & 1.35 & 0.78 \\
\hline $\mathrm{CH}_{3} \mathrm{CN}$ & 320 & 436 & 1.75 & 0.82 \\
\hline $\mathrm{DMF}$ & 324 & 436 & 1.69 & 0.86 \\
\hline EtOH & 321 & 439 & 1.90 & 0.78 \\
\hline $\mathrm{MeOH}$ & 322 & 452 & 1.87 & 0.57 \\
\hline solid state & - & 428 & 1.32 & - \\
\hline
\end{tabular}

${ }^{a}$ Lowest energy absorption band. ${ }^{b}$ Upon excitation of the lowest energy absorption band. ${ }^{c}$ Fluorescence lifetime. ${ }^{d}$ Relative fluorescence quantum yield.
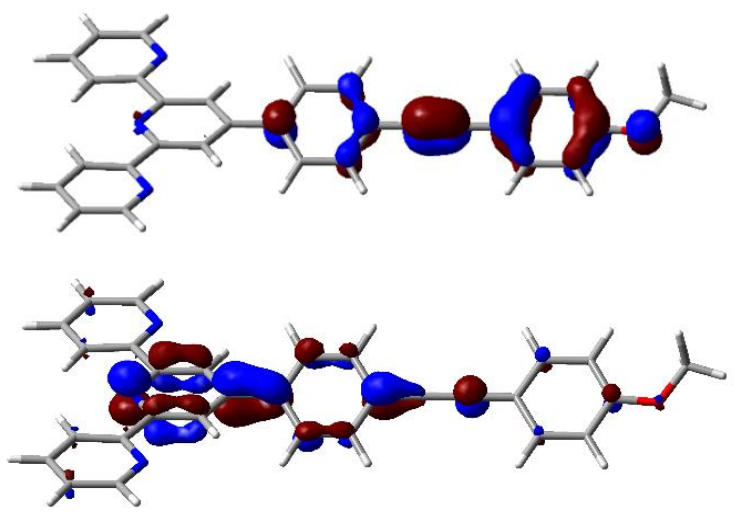

Fig. 7 Isosurface plots of the highest occupied Kohn-Sham molecular orbital (HOMO, top) and lowest unoccupied Kohn-Sham molecular orbital (LUMO, bottom) of $\mathbf{L}$ calculated at the PBE1PBE/TZVP level of theory.

The influence of solvent effects to the calculated absorption properties was also tested by performing calculations on the solute placed in a cavity within the solvent reaction field (either acetonitrile or dichloromethane, see ESI $\dagger$ ). The results show that solvent effect modelled with an implicit solvent model changes the calculated absorption wavelength only by $5 \mathrm{~nm}$, in agreement with the insensitivity of the experimental absorption maximum to the used solvent (Table 3 ).

Fig. 6 also shows the UV-Vis spectra of complexes 1-5 measured in dichloromethane at room temperature. Significant changes are observed in the spectrum of $\mathbf{L}$ upon complex formation. Most notably, the UV region of the absorption spectra is clearly dominated by spin-allowed ligand-centered (LC) $\pi \rightarrow \pi^{*}$ transition(s) at around $340 \mathrm{~nm}$. The transitions observed for complexes 1-4 in the wavelength range 360-380 $\mathrm{nm}$ are presumably of metal induced intra-ligand charge transfer (ILCT) type as discussed recently in the case of related 
$\mathrm{Zn}$ (II)-terpyridine complexes. ${ }^{37 \mathrm{~d}} \mathrm{We}$ tested this by calculating the transitions for 2 at the PBE1PBE/TZVP level using the TDDFT formalism and the crystal structure geometry of the salt. The calculations reveal several high-intensity absorptions in between 300 and $400 \mathrm{~nm}$ of which the most intense appear at 340 and $399 \mathrm{~nm}$. As expected, these two transitions involve intra-ligand excitations from the diphenylacetylene moiety to the terpyridine framework (primarily from HOMO and HOMO2 to LUMO and LUMO+1, see ESI $\dagger$ ). The complexes 1 and 4 also exhibit typical metal to ligand charge-transfer (MLCT) transitions in the visible region of the spectra. The MLCT bands for 1 and 4 are observed at 574 and $497 \mathrm{~nm}$, respectively, and are very close to those reported for [Fe(biphterpy) $\left.{ }_{2}\right]^{2+}(571$ $\mathrm{nm})$ and $\left[\mathrm{Ru}(\text { biphterpy })_{2}\right]^{2+}(494 \mathrm{~nm})$ (biphterpy $=4^{\prime}-$

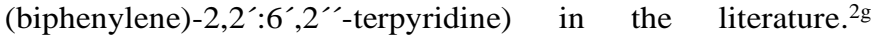
Although the LC and MLCT transitions are not influenced by solvent polarity, the ILCT bands of complexes 1-4 become increasingly broadened when using highly polar solvents.

\section{Emission spectroscopy and DFT calculations}

The ligand $\mathbf{L}$ displays bright blue emission upon irradiation by UV light. Upon excitation of the absorption maximum of $\mathbf{L}$ at $322 \mathrm{~nm}$ in dichloromethane, a single intense band is observed in the recorded emission spectrum, indicating that the fluorescence involves only one excited state. To probe the fluorescence properties of $\mathbf{L}$ further, its emission spectrum was recorded in different solvents and the results are summarized in Table 3 (see ESI $\dagger$ ). Even though the absorption maximum of $\mathbf{L}$ was mostly unperturbed by the polarity of the solvent, its emission maximum displays significant solvatochromism (Fig. 8). This suggests that the first excited state of the monoterpyridine ligand $\mathbf{L}$ has a relatively high dipole moment compared to the ground state.

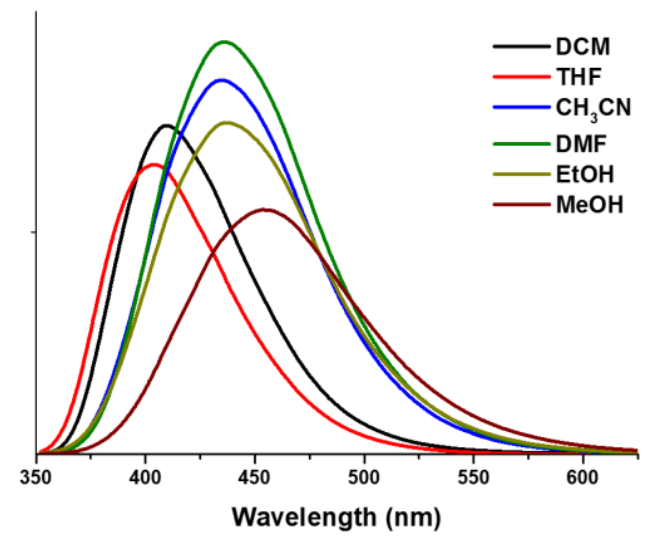

Fig. 8 Emission spectra of $\mathbf{L}$ in different solvents $\left(25^{\circ} \mathbf{C}\right)$.

The ligand $\mathbf{L}$ displays relatively high quantum yield in a range of different solvents (Table 3). Mono-terpyridine ligands rarely possess good emissive characteristics and to the best of our knowledge, $\mathbf{L}$ has one of the highest quantum yields $\left(\Phi_{\mathrm{F}}=\right.$ 0.85 in $N, N$-dimethylformamide) reported so far for any terpyridine compound of its kind. ${ }^{11 e}$, 12a Surprisingly, the fluorescence of $\mathbf{L}$ is only mildly affected even in polar protic solvents such as ethanol and methanol, a result which is in stark contrast to literature reports on analogous terpyridine ligands such as $4^{\prime}-\left(4-N, N\right.$-dimethylaminophenyl)-2,2': $6^{\prime}, 2^{\prime \prime}$ -

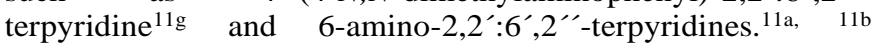

Studying the fluorescence decay behavior of $\mathbf{L}$ in different solvents shows that its fluorescence lifetime increases with the polarity of the solvent. The ligand $\mathbf{L}$ retains its fluorescence also in the solid state. ${ }^{38}$ Many fluorescent compounds, particularly $\pi$ conjugated systems, lose their emissive properties in the solid state due to increasing intermolecular interactions that induce non-radiative deactivation pathways. ${ }^{39}$ In case of $\mathbf{L}$, the molecules form $\pi$-stacked dimers in the solid state structure and the weak $\pi \cdots \pi$ interactions between the adjacent terpyridine moieties (Fig. 3) do not have any significant influence to the parts of the molecule responsive of the observed fluorescence (see below).

DFT geometry optimizations (at PBE1PBE/TZVP level) conducted for the first excited state of the ligand $\mathbf{L}$ show that its structure is in many respects very similar to that of the ground state (see ESI $\dagger$ ). The most notable difference is the shortening of the $\mathrm{C} 11-\mathrm{C} 19$ bond that connects the terpyridine unit to the diphenylacetylene moiety from 1.475 to $1.445 \AA$ (gas phase data). In addition, the ligand twists to a conformation in which all of its pyridyl and phenyl rings are nearly coplanar. These changes are consistent with the morphology of the LUMO of $\mathbf{L}$ which shows increased conjugation between the central pyridyl ring and the diphenylacetylene moiety (Fig. 7). As discussed earlier, the frontier orbitals of $\mathbf{L}$ indicate that significant internal charge transfer takes place upon electronic excitation, which readily explains the change in the calculated dipole moment from 1.9 to $13.7 \mathrm{D}$, thereby rationalizing the relatively large Stokes shit observed for $\mathbf{L}$ in highly polar environments (Table 3).

TD-DFT calculations conducted for the first excited state of $\mathbf{L}$ predict an emission wavelength of $393 \mathrm{~nm}$ in the gas phase. The inclusion of solvent effect with an implicit solvent model changes the calculated emission wavelength to 439 (dichloromethane) and $447 \mathrm{~nm}$ (acetonitrile). These data are in reasonable agreement with the experimentally determined emission maximum of $\mathbf{L}$ in different solvent systems (Table 3 ). The LUMO of $\mathbf{L}$ (Fig. 7) shows that the electronic excitation involves an orbital with virtually no contribution from atoms of the terminal pyridyl and phenyl rings. This differs considerably from the morphology of the LUMO of the parent terpyridine ligand (see ESI $\dagger$ ) and offers a plausible explanation as to why $\mathbf{L}$ shows such a high quantum yield in different environments. Typically molecules that have high degree of flexibility show poor fluorescence properties due to promotion of non-radiative decay pathways. In case of $\mathbf{L}$, the orbital most relevant to its fluorescence properties displays extended $\pi$-conjugation and is fully confined to a structurally rigid part in the molecular skeleton. In contrast, in typical terpyridine systems the lowest excitation is of singlet $n-\pi^{*}$ type, which causes a rapid intersystem crossing to a triplet $n-\pi^{*}$ state and no fluorescence of the terpyridine is observed. ${ }^{12}$

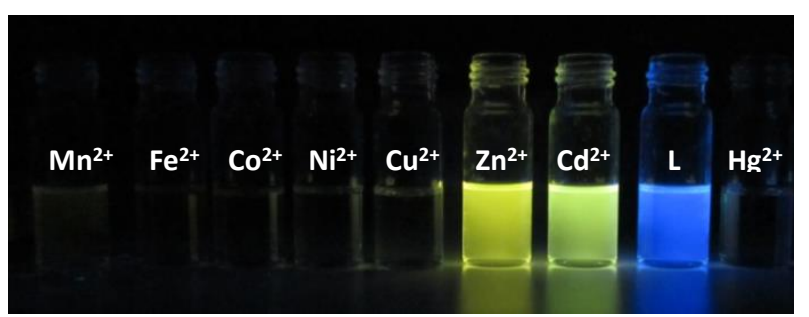

Fig. 9 Fluorescence of $\mathbf{L}\left(2.5 \times 10^{-5} \mathrm{M}\right.$ in dichloromethane $)$ in the presence of different divalent metal ions $(0.5$ eq. as perchlorate salts in acetonitrile) under UV-lamp (365 nm) at $25^{\circ} \mathrm{C}$. 
Fig. 9 shows the effect of coordination to different divalent transition metal ions on the fluorescence of the terpyridine ligand $\mathbf{L}$. It is evident that the fluorescence of $\mathbf{L}$ becomes completely quenched upon adding metals such as $\mathrm{Mn}^{2+}, \mathrm{Fe}^{2+}$, $\mathrm{Co}^{2+}, \mathrm{Ni}^{2+}, \mathrm{Cu}^{2+}$ and $\mathrm{Hg}^{2+}$, whereas the addition of $\mathrm{Zn}^{2+}$ and $\mathrm{Cd}^{2+}$ (that is, complexes 2 and 3) results in greenish-yellow fluorescence (see ESI $\dagger$ ). However, compared to the free ligand $\mathbf{L}$, the $\mathrm{Zn}(\mathrm{II})$ and $\mathrm{Cd}(\mathrm{II})$ complexes show only weak fluorescence with an emission maximum at longer wavelengths (Fig. 10).

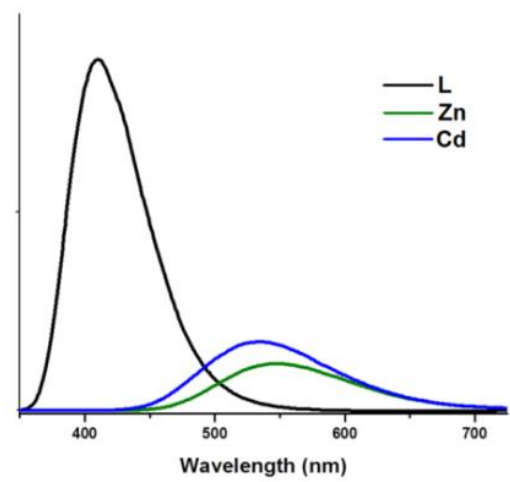

Fig. 10 Fluorescence spectra of the terpyridine ligand $\mathbf{L}\left(2.5 \times 10^{-5} \mathrm{M}\right.$ in dichloromethane, $25^{\circ} \mathrm{C}$ ) and in the presence of $\mathrm{Zn}^{2+}$ and $\mathrm{Cd}^{2+}$ metal ions ( 0.5 eq. as perchlorate salts in acetonitrile, $\left.25^{\circ} \mathrm{C}\right)$.

The quenching of ligand fluorescence by transition metal ions during complex formation is a rather common phenomenon. ${ }^{40} \mathrm{~A}$ transition-metal center can induce quenching through electron transfer or energy transfer mechanisms. ${ }^{41}$ Upon complexation with terpyridines, the $\mathrm{Ru}(\mathrm{II})$ complexes produce a MLCT type singlet excited state, ${ }^{1}$ MLCT, which quickly gives rise to the corresponding triplet state, ${ }^{3}$ MLCT. The ${ }^{3}$ MLCT state is short lived due to efficient thermally activated decay via a proximal ${ }^{3} \mathrm{~d}-\mathrm{d}$ state. For this reason, no fluorescence is observed for $\mathrm{Ru}(\mathrm{II})$ (or $\mathrm{Fe}(\mathrm{II})$ ) complexes of terpyridines. $^{1 \mathrm{e}, 42}$ In case of $\mathrm{Zn}(\mathrm{II})$ or $\mathrm{Cd}(\mathrm{II})$ complexes, the filled $\mathrm{d}^{10}$ shell makes the metals inoffensive from a photophysical point of view as they cannot be involved in an electron transfer processes nor do they show redox activity required for photo-induced electron transfer. Hence, in $\mathrm{Zn}$ (II) and $\mathrm{Cd}(\mathrm{II})$ systems, fluorescence from ILCT type excited states to the ground state is readily observed. ${ }^{11 \mathrm{~g}, 43}$

Table 4 gives a summary of the photophysical properties of $\mathbf{2}$ and $\mathbf{3}$ in different solvents. The emission maxima of both complexes is red-shifted with increasing solvent polarity, which is consistent with the ILCT state being the excited state. Significant quenching is observed in solvents of high polarity as indicated by the fluorescence quantum yields. The fluorescence lifetimes of $\mathbf{2}$ and $\mathbf{3}$ follow the aforementioned trend. The metal complexes $\mathbf{2}$ and $\mathbf{3}$ show noticeable green fluorescence also in the solid state with a considerably longer fluorescence lifetime than that found for $\mathbf{L}$ (1.32 ns).

Although $\mathbf{2}$ and $\mathbf{3}$ exhibit fluorescence in solution and in the solid state, complexes $\mathbf{1}, \mathbf{4}$ and $\mathbf{5}$ are non-fluorescent irrespective of the environment. It should also be mentioned that complex $\mathbf{5}$ is soluble to most polar aprotic solvents but only sparingly soluble in protic solvents such as methanol and ethanol. In addition, at higher dilutions in these solvents, extensive dissociation of the complex takes place for which reason its emission spectra shows the characteristics of the free ligand.
Table 4 Photophysical properties of $\mathbf{2}$ and $\mathbf{3}$ in different solvents and in the solid state

\begin{tabular}{l|l|l|l|l|l|}
\hline Complex & System & $\lambda_{\max }{ }^{\text {abs }}(\mathrm{nm})^{a}$ & $\lambda_{\max }{ }^{\mathrm{em}}(\mathrm{nm})^{b}$ & $\tau_{\mathrm{F}}(\mathrm{ns})^{c}$ & $\Phi_{\mathrm{F}}{ }^{d}$ \\
\hline \multirow{2}{*}{} & $\mathrm{DCM}$ & 377 & 542 & 2.02 & 0.19 \\
\cline { 2 - 6 } & $\mathrm{THF}$ & 367 & 535 & 1.46 & 0.11 \\
\cline { 2 - 6 } & $\mathrm{CH}_{3} \mathrm{CN}$ & 365 & 572 & 0.85 & 0.03 \\
\cline { 2 - 6 } & $\begin{array}{l}\text { Solid- } \\
\text { state }\end{array}$ & - & 505 & 4.37 & - \\
\hline $\mathbf{3}$ & $\mathrm{DCM}$ & 374 & 532 & 1.88 & 0.21 \\
\cline { 2 - 6 } & $\mathrm{THF}$ & 368 & 524 & 1.35 & 0.16 \\
\cline { 2 - 6 } & $\mathrm{CH}_{3} \mathrm{CN}$ & 365 & 565 & 0.78 & 0.03 \\
\cline { 2 - 6 } & $\begin{array}{l}\text { Solid- } \\
\text { state }\end{array}$ & - & 523 & 4.33 & - \\
\hline
\end{tabular}

${ }^{a}$ Absorbance of the lowest energy absorption band. ${ }^{b}$ Upon excitation of the lowest energy absorption band. ${ }^{c}$ Fluorescence lifetime. ${ }^{d}$ Relative fluorescence quantum yield.

\section{Conclusions}

In conclusion, a new hybrid luminescent fluorophore $4^{\prime}-[4-\{4-$ methoxyphenyl)ethynyl $\}$ phenyl]-2,2':6',2'"-terpyridine ligand $\mathbf{L}$, constructed by combining the diphenylacetylene moiety with the terpyridine framework, is described together with its structural and photophysical properties. Several transition metal complexes of $\mathbf{L}$ were also synthesized and characterized in detail. The structural investigations show that the ligand binds to common divalent metal ions in tridentate fashion but forms a bidentate complex with trimethylplatinum(IV) iodide. The synthesized ligand is highly emissive in both solid state and in non-polar solutions, and retains its efficiency even in polar organic media - a property that is unique among monoterpyridine ligands. Results from density functional theory calculations associate the luminescence of $\mathbf{L}$ to an intraligand charge transfer state that involves electronic excitation from the diphenylacetylene moiety to the terpyridine framework. The influence of metal coordination on the photophysical properties of $\mathbf{L}$ has also been investigated. Although the $\mathrm{Fe}(\mathrm{II}), \mathrm{Ru}(\mathrm{II})$ and $\mathrm{Pt}(\mathrm{IV})$ complexes of $\mathbf{L}$ do not show any fluorescence, its $\mathrm{Zn}$ (II) and $\mathrm{Cd}(\mathrm{II})$ complexes exhibit strong green luminescence with significant solvatochromism. The new fluorescent ligand $\mathbf{L}$ and its $\mathrm{Zn}$ and $\mathrm{Cd}$ complexes are currently being investigated for their use in optoelectronics.

\section{Acknowledgements}

We thank Dr. Heli Lehtivuori and Dr. Sandip Bhowmik for fluorescence lifetime measurements and useful discussions, respectively. The Academy of Finland (K.R. grants 256259, 265328, and 263256), the Technology Industries of Finland Centennial Foundation (J.L. and H.M.T) and DST India (P.M. grant INT/FINLAND/P-06 and SR/S1/IC-59/2010) are gratefully acknowledged for financial support. P.K.S. thanks UGC India for a fellowship. F.T. acknowledges the support from NGS-NANO through a Ph.D. fellowship.

\section{Notes and references}

${ }^{a}$ Department of Chemistry, Nanoscience Center, University of Jyväskylä, P.O. Box 35, 40014 Jyväskylä, Finland. Fax: +358 14 2602501; Tel: 358-50-5623721; E-mail: kari.t.rissanen@jyu.fi 
${ }^{b}$ Department of Chemistry, Veer Surendra Sai University of Technology, Burla, Sambalpur-768018, Odisha, India.

${ }^{c}$ School of Chemical Sciences, National Institute of Science Education and Research (NISER) Bhubaneswar; Institute of Physics Campus, P.O. Sainik School; Bhubaneswar, Odisha 751005, India.

(a) U. S. Schubert, H. Hofmeier and G. R. Newkome, Modern terpyridine chemistry, Wiley-VCH, Weinheim, 2006; (b) A. Wild, A. Winter, F. Schlütter and U. S. Schubert, Chem. Soc. Rev., 2011, 40, 1459-1511; (c) E. C. Constable, Chem. Soc. Rev., 2007, 36, 246-253; (d) M. W. Cooke and G. S. Hanan, Chem. Soc. Rev., 2007, 36, 1466-1476; (e) E. A. Medlycott and G. S. Hanan, Chem. Soc. Rev., 2005, 34, 133-142.

$2 . \quad$ (a) D. Wang, Q.-L. Xu, S. Zhang, H.-Y. Li, C.-C. Wang, T.-Y. Li, Y.-M. Jing, W. Huang, Y.-X. Zheng and G. Accorsi, Dalton Trans., 2013, 42, 2716-2723; (b) Y.-M. Zhang, S.-H. Wu, C.-J. Yao, H.-J. Nie and Y.-W. Zhong, Inorg. Chem., 2012, 51, 1138711395; (c) Y. H. Lee, E. Kubota, A. Fuyuhiro, S. Kawata, J. M. Harrowfield, Y. Kim and S. Hayami, Dalton Trans., 2012, 41, 10825-10831; (d) H.-X. Zhang, M. Kato, Y. Sasaki, T. Ohba, H. Ito, A. Kobayashi, H.-C. Chang and K. Uosaki, Dalton Trans., 2012, 41, 11497-11506; (e) B. Schulze, C. Friebe, M. D. Hager, A. Winter, R. Hoogenboom, H. Görls and U. S. Schubert, Dalton Trans., 2009, 787-794; (f) D. P. Funeriu, K. Rissanen and J.-M. P. Lehn, Proc. Natl. Acad. Sci. USA, 2001, 98, 10546-10551; (g) N. W. Alcock, P. R. Barker, J. M. Haider, M. J. Hannon, C. L. Painting, Z. Pikramenou, E. A. Plummer, K. Rissanen and P. Saarenketo, J. Chem. Soc., Dalton Trans., 2000, 1447-1462.

3. A. Reynal and E. Palomares, Eur. J. Inorg. Chem., 2011, 45094526.

$4 . \quad$ L. S. Natrajan, A. Toulmin, A. Chew and S. W. Magennis, Dalton Trans., 2010, 39, 10837-10846.

5. (a) W. Kaim and G. K. Lahiri, Angew. Chem. Int. Ed., 2007, 46, 1778-1796; (b) C.-J. Yao, Y.-W. Zhong and J. Yao, J. Am. Chem. Soc., 2011, 133, 15697-15706.

6. (a) C.-J. Yao, Y.-W. Zhong, H.-J. Nie, H. D. Abruña and J. Yao, J. Am. Chem. Soc., 2011, 133, 20720-20723; (b) C.-J. Yao, J. Yao and Y.-W. Zhong, Inorg. Chem., 2012, 51, 6259-6263.

7. R. C. Evans, P. Douglas and C. J. Winscom, Coord. Chem. Rev., 2006, 250, 2093-2126.

8. (a) B. N. Ghosh, S. Bhowmik, P. Mal and K. Rissanen, Chem. Commun., 2014, 50, 734-736; (b) A. Griffith, T. J. Bandy, M. Light and E. Stulz, Chem. Commun., 2013, 49, 731-733; (c) F. D. Jochum, J. Brassinne, C.-A. Fustin and J.-F. Gohy, Soft Matter, 2013, 9, 2314-2320.

9. (a) G. Raj, C. Swalus, A. Guillet, M. Devillers, B. Nysten and E. M. Gaigneaux, Langmuir, 2013, 29, 4388-4395; (b) S. Banerjee, R. K. Das and U. Maitra, J. Mater. Chem., 2009, 19, 6649-6687; (c) E. Busseron, Y. Ruff, E. Moulin and N. Giuseppone, Nanoscale, 2013, 5, 7098-7140; (d) S. Nardecchia, D. Carriazo, M. L. Ferrer, M. C. Gutiérrez and F. del Monte, Chem. Soc. Rev., 2013, 42, 794-830.

10. (a) S. Bhowmik, B. N. Ghosh, V. Marjomäki and K. Rissanen, $J$ Am. Chem. Soc., 2014, 136, 5543-5546; (b) L. J. Liang, X. J. Zhao and C. Z. Huang, The Analyst, 2012, 137, 953-958; (c) P. Das, A. Ghosh, M. K. Kesharwani, V. Ramu, B. Ganguly and A. Das, Eur. J. Inorg. Chem., 2011, 3050-3058; (d) X. Peng, Y. Xu, S. Sun, Y. Wu and J. Fan, Org. Biomol. Chem., 2007, 5, 226-228.

11. (a) J.-D. Cheon, T. Mutai and K. Araki, Org. Biomol. Chem., 2007, 5, 2762-2766; (b) T. Mutai, J.-D. Cheon, G. Tsuchiya and K. Araki, J. Chem. Soc., Perkin Trans. 2, 2002, 862-865; (c) W. Goodall, K. Wild, K. J. Arm and J. A. G. Williams, J. Chem. Soc., Perkin Trans. 2, 2002, 1669-1681; (d) T. Mutai, J.-D. Cheon, S. Arita and K. Araki, J. Chem. Soc., Perkin Trans. 2, 2001, 10451050; (e) J. C. Loren and J. S. Siegel, Angew. Chem. Int. Ed., 2001, 40, 754-757; (f) P. N. W. Baxter, Chem. Eur. J., 2003, 9 , 5011-5022; (g) W. Goodall and J. A. G. Williams, Chem. Commun., 2001, 2514-2515.

12. (a) A. Winter, C. Friebe, M. D. Hager and U. S. Schubert, Eur. J. Org. Chem., 2009, 801-809; (b) A. Winter, D. A. M. Egbe and U. S. Schubert, Org. Lett., 2007, 9, 2345-2348; (c) M. Presselt, B. Dietzek, M. Schmitt, S. Rau, A. Winter, M. Jäger, U. S. Schubert and J. Popp, J. Phys. Chem. A, 2010, 114, 13163-13174. (a) J. Saltiel and V. K. R. Kumar, J. Phys. Chem. A, 2012, 116, 10548-10558; (b) M. Z. Zgierski, T. Fujiwara and E. C. Lim, Acc. Chem. Res., 2010, 43, 506-517; (c) Q. Chu and Y. Pang, Spectrochim. Acta Part A, 2004, 60, 1459-1467; (d) Y. Hirata, Bull. Chem. Soc., Jpn., 1999, 72, 1647-1664; (e) C. Ferrante, U. Kensy and B. Dick, J. Phys. Chem., 1993, 97, 13457-13463; (f) Y. Hirata, T. Okada, N. Mataga and T. Nomoto, J. Phys. Chem., 1992, 96, 6559-6563; (g) R. C. Henson and E. D. Owen, Chem. Commun., 1967, 153-164; (h) D. R. Borst, S. G. Chou and D. W. Pratt, Chem. Phys. Lett., 2001, 343, 289-295; (i) K. Okuyama, T. Hasegawa, M. Ito and N. Mikami, J. Phys. Chem., 1984, 88, 1711-1716; (j) M. Gutmann, M. Gudipati, P.-F. Schönzart and G. Hohlneicher, J. Phys. Chem., 1992, 96, 2433-2442.

E. C. Constable, C. E. Housecroft, S. L. Kokatam, E. A. Medlycott and J. A. Zampese, Inorg. Chem. Commun., 2010, 13, 457-460.

15. J. Wang and G. S. Hanan, Synlett, 2005, 1251-1254.

16. R. W. Hooft, in COLLECT, Nonius BV, Delft, The Netherlands, 1998.

17. Z. Otwinowski and W. Minor, Methods in Enzymology, Macromolecular Crystallography, Part A, New York: Academic Press, 1997.

18. G. M. Sheldrick, SADABS, Bruker Analytical X-ray system, Inc., Madison, Wisconsin, 2008.

19.

20.

21.

22.

23.

24.

CrysAlisPro, 2013, Agilent Technologies. Version 1.171.136.128. R. C. Clark and J. S. Reid, Acta Cryst., 1995, A51, 887-897.

L. Palatinus and G. Chapuis, J. Appl. Cryst., 2007, 40, 786-790.

L. Farrugia, J. Appl. Cryst., 2012, 45, 849-854.

G. M. Sheldrick, Acta Cryst. , 2008, A64, 112-122.

C. F. Macrae, I. J. Bruno, J. A. Chisholm, P. R. Edgington, P. McCabe, E. Pidcock, L. Rodriguez-Monge, R. Taylor, J. van de Streek and P. A. Wood, J. Appl. Cryst., 2008, 41, 466-470.

F. H. Allen, Acta Cryst., 2002, B58, 380-388.

26.

(a) J. P. Perdew, K. Burke and M. Ernzerhof, Phys. Rev. Lett., 1996, 77, 3865-3868; (b) J. P. Perdew, M. Ernzerhof and K. Burke, J. Chem. Phys., 1996, 105, 9982-9985; (c) J. P. Perdew, K. Burke and M. Ernzerhof, Phys. Rev. Lett., 1997, 78, 1396-1400; (d) C. Adamo and V. Barone, J. Chem. Phys., 1999, 110, 61586170.

27. A. Schäfer, C. Huber and R. Ahlrichs, J. Chem. Phys., 1994, 100, 5829-5835.

28. R. Bauernschmitt and R. Ahlrichs, Chem. Phys. Lett., 1996, 256, 454-464.

29. J. Tomasi, B. Mennucci and R. Cammi, Chem. Rev., 2005, 105, 2999-3093.

30. M. J. Frisch, G. W. Trucks, H. B. Schlegel, G. E. Scuseria, M. A. Robb, J. R. Cheeseman, G. Scalmani, V. Barone, B. Mennucci, G. A. Petersson, H. Nakatsuji, M. Caricato, X. Li, H. P. Hratchian, A. F. Izmaylov, J. Bloino, G. Zheng, J. L. Sonnenberg, M. Hada, M. Ehara, K. Toyota, R. Fukuda, J. Hasegawa, M. Ishida, T. Nakajima, Y. Honda, O. Kitao, H. Nakai, T. Vreven, J. A. Montgomery, Jr., J. E. Peralta, F. Ogliaro, M. Bearpark, J. J. Heyd, E. Brothers, K. N. Kudin, V. N. Staroverov, R. Kobayashi, J. Normand, K. Raghavachari, A. Rendell, J. C. Burant, S. S. Iyengar, J. Tomasi, M. Cossi, N. Rega, N. J. Millam, M. Klene, J. E. Knox, J. B. Cross, V. Bakken, C. Adamo, J. Jaramillo, R. Gomperts, R. E. Stratmann, O. Yazyev, A. J. Austin, R. Cammi, C. Pomelli, J. W. Ochterski, R. L. Martin, K. Morokuma, V. G. Zakrzewski, G. A. Voth, P. Salvador, J. J. Dannenberg, S. Dapprich, A. D. Daniels, Ö. Farkas, J. B. Foresman, J. V. Ortiz, J. Cioslowski and D. J. Fox, Gaussian 09, Revision A.1; Gaussian, Inc.: Wallingford CT, 2009.

31. R. Dennington, T. Keith and J. Millam, GaussView, Version 5, Semichem Inc., Shawnee Mission KS, 2009.

32. (a) E. W. Abel, V. S. Dimitrov, N. J. Long, K. G. Orrell, A. G. Osborne, V. Šik, M. B. Hursthouse and M. A. Mazid, J. Chem. Soc., Dalton Trans., 1993, 291-298; (b) E. W. Abel, N. J. Long, K. G. Orrell, A. G. Osborne, H. M. Pain and V. Šik, J. Chem. Soc., Chem. Commun., 1992, 303-304.

33. F. G. Baddour, M. I. Kahn, J. A. Golen, A. L. Rheingold and L. H. Doerrer, Chem. Commun., 2010, 46, 4968-4970.

34. (a) B. Liu, Q. Zhang, H. Ding, G. Hu, Y. Du, C. Wang, J. Wu, S. Li, H. Zhou, J. Yang and Y. Tian, Dyes \& Pigments, 2012, 95, 
149-160; (b) C. Bhaumik, S. Das, D. Maity and S. Baitalik, Dalton Trans., 2011, 40, 11795-11808; (c) A. Winter, A. M. J. van den Berg, R. Hoogenboom, G. Kickelbick and U. Schubert, Synthesis, 2006, 2873-2878.

35. (a) W. Leslie, A. S. Batsanov, J. A. K. Howard and J. A. G. Williams, Dalton Trans., 2004, 623-631; (b) E. C. Constable, B. Kariuki and A. Mahmood, Polyhedron, 2003, 22, 687-698.

36. (a) E. C. Constable, C. E. Housecroft, J. R. Price, L. Schweighauser and J. A. Zampese, Inorg. Chem. Commun., 2010, 13, 495-497; (b) J. E. Beves, P. Chwalisz, E. C. Constable, C. E. Housecroft, M. Neuburger, S. Schaffner and J. A. Zampese, Inorg. Chem. Commun., 2008, 11, 1009-1011; (c) E. A. Medlycott, G. S. Hanan, T. S. M. Abedin and L. K. Thompson, Polyhedron, 2008, 27, 493-501; (d) J. E. Beves, D. J. Bray, J. K. Clegg, E. C. Constable, C. E. Housecroft, K. A. Jolliffe, C. J. Kepert, L. F. Lindoy, M. Neuburger, D. J. Price, S. Schaffner and F. Schaper, Inorg. Chim. Acta, 2008, 361, 2582-2590; (e) J. E. Beves, E. C. Constable, C. E. Housecroft, C. J. Kepert, M. Neuburger, D. J. Price and S. Schaffner, CrystEngComm, 2007, 9, 1073-1077.

37. (a) E. C. Constable, C. E. Housecroft, N. S. Murray and J. A. Zampese, Polyhedron, 2013, 54, 110-118; (b) B. Maity, S. Gadadhar, T. K. Goswami, A. A. Karande and A. R. Chakravarty, Dalton Trans., 2011, 40, 11904-11913; (c) W. You, W. Huang, Y. Fan and C. Yao, J. Coord. Chem., 2009, 62, 2125-2137; (d) X. Chen, Q. Zhou, Y. Cheng, Y. Geng, D. Ma, Z. Xie and L. Wang, J. Luminescence, 2007, 126, 81-90; (e) G.-J. Chen, Z.-G. Wang, Y.-Y. Kou, J.-L. Tian and S.-P. Yan, J. Inorg. Biochem., 2013, 122, 49-56.

38. T. Mutai, H. Satou and K. Araki, Nat. Mater., 2005, 4, 685-687.

39. (a) M. Moffitt, J. P. S. Farinha, M. A. Winnik, U. Rohr and K. Müllen, Macromolecules, 1999, 32, 4895-4904; (b) F. Würthner, C. Thalacker, S. Diele and C. Tschierske, Chem. Eur. J., 2001, 7, 2245-2253.

$40 . \quad$ (a) A. W. Varnes, R. B. Dodson and E. L. Wehry, J. Am. Chem. Soc., 1972, 94, 946-950; (b) J. A. Kemlo and T. M. Sheperd, Chem. Phys. Lett., 1977, 47, 158-162.

41. V. Balzani and F. Scandola, Supramolecular Photochemistry, Ellis Horwood: London, 1991.

42. (a) R. C. Young, J. K. Nagle, T. J. Meyer and D. G. Whitten, J. Am. Chem. Soc., 1978, 100, 4773-4778; (b) J. R. Kirchhoff, D. R. McMillin, P. A. Marnot and J. P. Sauvage, J. Am. Chem. Soc., 1985, 107, 1138-1141.

43. (a) W. Goodall and J. A. G. Williams, J. Chem. Soc., Dalton Trans., 2000, 2893-2895; (b) X.-y. Wang, A. D. Guerzo and R. H. Schmehl, Chem. Commun., 2002, 2344-2345; (c) G. Albano, V. Balzani, E. C. Constable, M. Maestri and D. R. Smith, Inorg. Chim. Acta, 1998, 277, 225-231; (d) H. Hofmeier and U. S. Schubert, Chem. Soc. Rev., 2004, 33, 373-399. 